\title{
Microbial Activity at Yucca Mountain
}

OSTI

\author{
Joanne M. Horn and Annemarie Meike \\ Introduced Materials Task, \\ Yucca Mountain Site Characterization Project
}

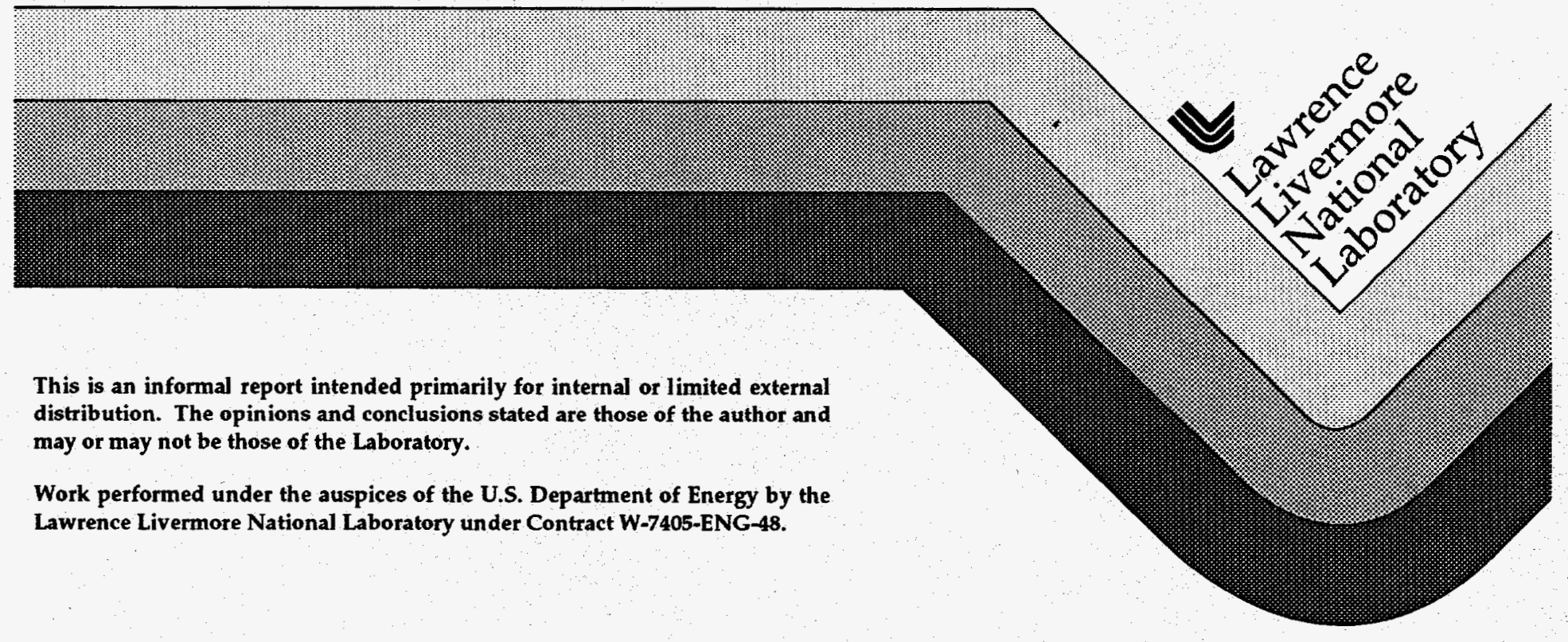

This is an informal report intended primarily for internal or limited external distribution. The opinions and conclusions stated are those of the author and may or may not be those of the Laboratory.

Work performed under the auspices of the U.S. Department of Energy by the Lawrence Livermore National Laboratory under Contract W-7405-ENG-48.

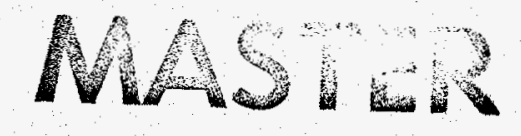




\section{Disclaimer}

This document was prepared as an account of work sponsored by an agency of the United States Government. Neither the United States Government nor the University of California nor any of their employees makes any warranty, express or implied, or assumes any legal liability or responsibility for the accuracy, completeness, or usefulness of any information, apparatus, product, or process disclosed, or represents that its use would not infringe privately owned rights. Reference herein to any specific commercial products, process, or service by trade name, trademark, manufacturer, or otherwise does not necessarily constitute or imply its endorsement, recommendation, or favoring by the United States Government or the University of California. The views and opinions of authors expressed herein do not necessarily state or reflect those of the United States Government thereof, and shall not be used for advertising or product endorsement purposes.

Work performed under the auspices of the U.S. Department of Energy by Lawrence Livermore National Laboratory under Contract W-7405Eng-48. 


\section{DISCLAMMER}

Portions of this document may be illegible in electronic image products. Images are produced from the best available original document. 


\section{Microbial Activity at Yucca Mountain}

PART I: Microbial Metabolism, Adaptation, and the Repository Environment

\section{Contents}

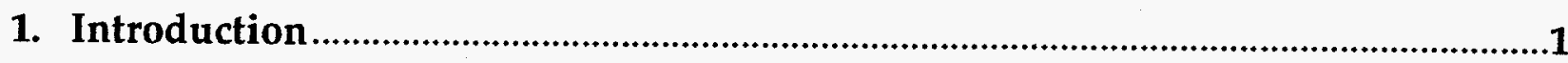

2. Considerations for Microbial Activity

2.1. Requirements for Microbial Growth..................................................................3

2.2. Microbial Modes, Adaptation to Stress, and Mutation.....................................

2.3. Limits to Microbial Growth and Activity ...........................................................

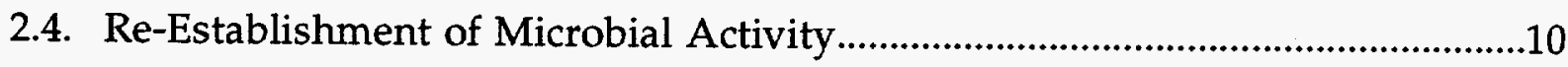

2.5. Chemical Consequences of Microbial Metabolism................................................11

2.6. Other Microbial Processes .................................................................................17

3. Microbial Considerations From a Repository Perspective........................................21

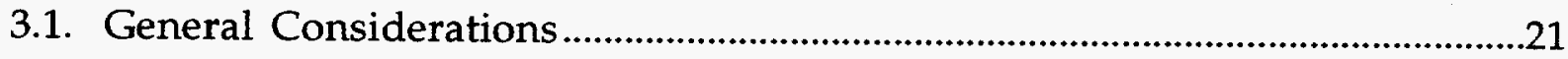

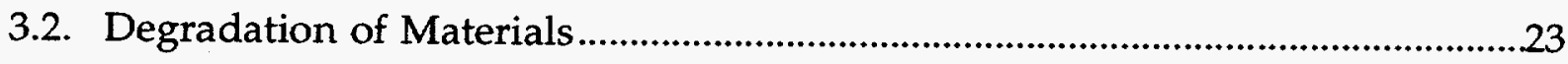

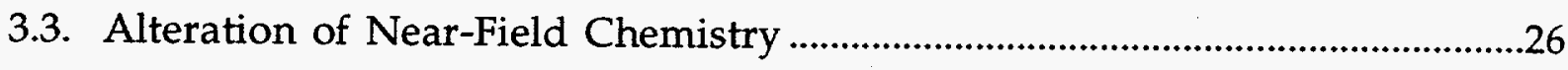

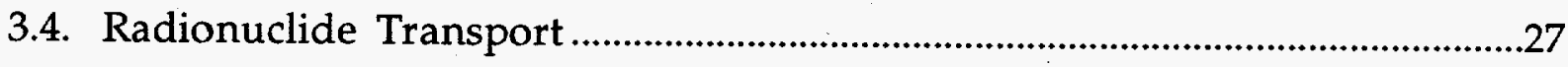

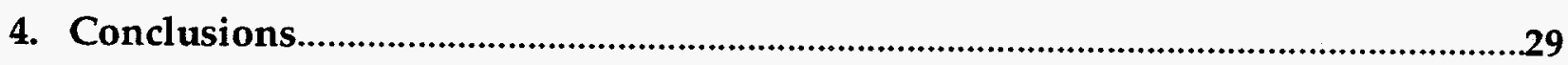

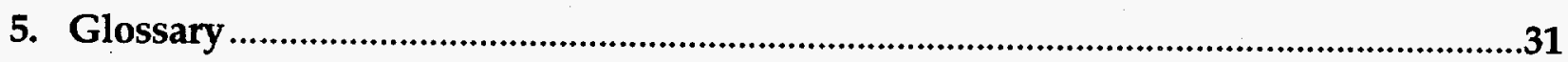

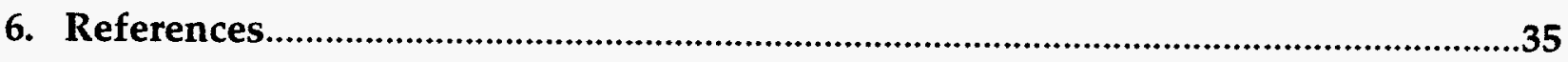

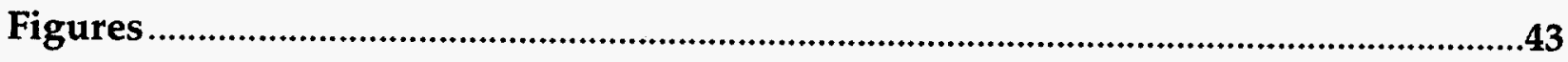

Appendix: Attendees of the Workshop on Microbial Activity at Yucca Mountain, April 10-12, 1995, Lafayette, California...............................................51 


\title{
MICROBIAL ACTIVITY AT YUCCA MOUNTAIN
}

\author{
PART I: Microbial Metabolism, Adaptation, \\ and the Repository Environment
}

\section{Introduction}

The U.S. Department of Energy is engaged in a suitability study for a potential geological repository at Yucca Mountain, Nevada, for the containment and storage of commercially generated spent fuel and defense high-level nuclear waste. There is growing recognition of the role that biotic factors could play in this repository, either directly through microbially induced corrosion (MIC), or indirectly by altering the chemical environment or contributing to the transport of radionuclides. As a first step toward describing and predicting these processes, a workshop was held on April 10-12, 1995, in Lafayette, California. The immediate aims of the workshop were:

(1) To identify microbially related processes relevant to the design of a radioactive waste repository under conditions similar to those at Yucca Mountain.

(2) To determine parameters that are critical to the evaluation of a disturbed subterranean environment.

(3) To define the most effective means of investigating the factors thus identified.

The workshop was attended by some of the Yucca Mountain principal investigators and recognized microbiologists (attendees are listed in the Appendix).

Key concepts that were identified as a result of this workshop will be presented in two parts. Part I reveals a general perspective that provides a foundation for developing the directions described in Part II (published separately). General aspects of microbial activity of significance to the long-term $(10,000$-year) perspective of microbial activity are outlined in Part I, Section 1. Generalized aspects of microbial activity that relate to repository conditions are examined in Part I, Section 2. Explicit implications of microbially related processes that might be expected for the Yucca Mountain repository are explored in Part I, Section 3. Part II suggests avenues of investigation that can be used to predict microbial affects in the repository environment. 
For the purpose of distinguishing pivotal points in the evolution of a repository, we distinguish microbial growth, or the production of bacterial cells, from microbial activity, death, and dormancy. Microbial growth involves the increase of cellular components and daughter cells, with concomitant chemical modification of the environment. Non-growing cells may not require the building blocks for cellular components that are needed for growth per se, but these cells still may be metabolically active (synthesizing cellular products), requiring an energy source, an electron acceptor, and water. Thus, non-growing cells still interact with the surrounding environment and therefore have the potential to modify its chemistry. During dormancy, on the other hand, microbes do not produce chemical changes in the environment, although the potential for microbial activity in the future still exists. We define death as the cessation of microbial activity and the loss of potential for future activity and growth. Dead and dormant cells, however, can still be involved in significant chemical processes such as radionuclide transport and supplying nutrients for the growth of other organisms. Sporulated cells can undergo exposure to extremely harsh conditions, but do not chemically modify the environment. Both spores and dormant cells (metabolic arrest) are capable of renewing growth and/or activity if conducive conditions arise. 


\section{Considerations for Microbial Activity}

\subsection{Requirements for Microbial Growth}

\subsubsection{In order to grow, microbes need water, carbon, micronutrients, and trace metals.}

Active microbial metabolism, whether maintenance or growth, always requires the presence of water. The fundamental nature of the carbon requirement is indicated in the categorization of microbes according to the form of carbon utilized. Heterotrophs utilize reduced organic forms of carbon, while autotrophs can completely satisfy carbon needs by fixing carbon dioxide. Micronutrients are bioavailable forms of nitrogen, phosphorous, sulfur, hydrogen, and oxygen. Trace metals are required for biosynthesis of cellular components (Brock and Madigan, 1991). These nutrients are required only for the production of new cells, and may not be necessary to support maintenance of extant cells.

\subsubsection{Energy is required to support active metabolism.}

Microbial energy metabolism can be viewed as an accounting of electron transfers. These electron transfers are mediated by a sequence of biochemical reactions. Energy, in the form of a utilizable reduced electron source, can be derived from a variety of compounds. Extracted electrons are used, together with a final electron acceptor, to generate biochemical forms of stored energy required to drive biosynthesis of cellular materials, as well as to maintain cells in the absence of growth. Energy sources and electron acceptors can be either organic or inorganic compounds (Table 1) (Stanier et al., 1976).

Heterotrophs generally derive both their carbon and electrons from reduced carbon compounds. These can be completely oxidized, with the concomitant generation of carbon dioxide and water, using diatomic oxygen as a terminal electron acceptor (aerobic metabolism). Alternatively, fermenting organisms only partially oxidize the reduced carbon substrate, generating organic alcohols and carboxylic acids as final products (Brock and Madigan, 1991).

Lithotrophic bacteria use reduced inorganic compounds as a source of electrons. For example, hydrogen gas, carbon monoxide, nitrogen, ammonia, nitrite, ferrous iron, elemental sulfur, hydrogen sulfide, and thiosulfate can be used as electron donors by different groups of microorganisms. Oxidation of these 
Table 1. Requirements for bacterial growth, and associated products.

\begin{tabular}{|c|c|c|}
\hline Nutrients & Use $\mathrm{e}^{*}$ & Endproducts \\
\hline carbohydrates & $\begin{array}{l}\text { carbon source } \\
\text { electron source }\end{array}$ & $\begin{array}{l}\text { cell components } \\
\text { organic acids } \\
\text { alcohols } \\
\mathrm{CO}_{2}\end{array}$ \\
\hline $\begin{array}{l}\text { carbon dioxide } \\
\text { (or soluble } \mathrm{CO}_{3}{ }^{2-}, \mathrm{HCO}_{3}{ }^{-} \text {, } \\
\mathrm{H}_{2} \mathrm{CO}_{3} \text { ) }\end{array}$ & $\begin{array}{l}\text { carbon source } \\
\text { electron acceptor }\end{array}$ & $\begin{array}{l}\text { cell components } \\
\text { methane, } \mathrm{CO}\end{array}$ \\
\hline $\begin{array}{l}\text { organic acids } \\
\text { amino acids } \\
\text { purines, pyrimidines }\end{array}$ & carbon and electron sources & $\begin{array}{l}\text { cell components } \\
\text { alcohols } \\
\text { organic acids } \\
\mathrm{CO}_{2}\end{array}$ \\
\hline hydrogen & electron source & water \\
\hline carbon monoxide & $\begin{array}{l}\text { electron source } \\
\text { electron acceptor } \\
\text { carbon source }\end{array}$ & $\begin{array}{l}\text { carbon dioxide } \\
\text { methane } \\
\text { cell components }\end{array}$ \\
\hline ammonia & electron source & $\mathrm{NO}_{2}^{-}, \mathrm{NO}_{3}^{-}$ \\
\hline ferrous iron & electron source & ferric iron \\
\hline $\begin{array}{l}\text { sulfur compounds } \\
\left(\mathrm{H}_{2} \mathrm{~S}, \mathrm{~S}^{0}, \mathrm{~S}_{2} \mathrm{O}_{3}{ }^{-2}, \mathrm{SO}_{4}{ }^{-2}\right)\end{array}$ & $\begin{array}{l}\text { electron source } \\
\text { electron acceptor }\end{array}$ & $\begin{array}{l}\text { sulfuric acid, } \mathrm{S}^{0} \\
\mathrm{H}_{2} \mathrm{~S}, \mathrm{~S}^{0}\end{array}$ \\
\hline oxygen & electron acceptor & water \\
\hline nitrate & electron acceptor & $\mathrm{NO}_{2}^{-}, \mathrm{N}_{2} \mathrm{O}, \mathrm{NO}, \mathrm{N}_{2}$ \\
\hline $\mathrm{NO}_{2}$ & electron source & nitrate/nitric acid \\
\hline $\mathrm{Fe}^{2+}$ & electron source & $\mathrm{Fe}^{3+}$ \\
\hline $\mathrm{Fe}^{3+}$ & electron acceptor & $\mathrm{Fe}^{2+}$ \\
\hline
\end{tabular}

*The use of oxygen as an electron acceptor is termed "aerobic metabolism" and requires oxic conditions, while use of other electron acceptors is termed "anaerobic metabolism." 
compounds generates water, carbon dioxide, ammonia, nitrite, nitrate, ferric iron, and sulfate, respectively, as end products from these electron sources (Atlas and Bartha, 1981).

Oxidized compounds that act as terminal electron sinks also vary according to the mode of microbial metabolism. Aerobes use oxygen as a final electron acceptor, while anaerobes use a wide array of inorganic compounds, such as nitrate and sulfate. Fermentative organisms use metabolites generated from the incomplete oxidation of the original substrate as a terminal electron sink, under oxygendeficient conditions (Stanier et al., 1976).

\subsubsection{Microbes exist in oxic and anoxic environments.}

Oxygen is required by aerobic organisms as a terminal electron acceptor. Thus aerobes require an oxygenated environment. Anaerobic microorganisms use alternative compounds as electron sinks, which alleviates their requirement for oxic habitats. Oxygen is actually toxic to many anaerobic organisms (Chapelle, 1993).

\subsubsection{Microbes are known to exist in extreme conditions.}

An optimal range of environmental conditions can be defined for the active growth of microbes. It has been well established that these optimal conditions can vary widely, however, depending on the type of bacteria. Bacteria are known to survive, be metabolically active, and even thrive at elevated temperatures, in very alkaline, acidic, and saline environments, and in high levels of ionizing radiation (See Table 2 for examples of temperature and $\mathrm{pH}$ tolerance) (Atlas and Bartha, 1981; Chapelle, 1993). Furthermore, similar organisms have been found in widely disparate locales. For example, species that are capable of surviving temperatures in excess of $100^{\circ} \mathrm{C}$ (thermophiles) have been identified in deep ocean vents, soils, and surface hot springs (Stetter, 1995).

\footnotetext{
Summary: Microbes have extremely diverse modes of metabolism and can survive in extreme environments. However, the effects of microorganisms on their surrounding environment depend on the presence of adequate nutrients and moisture to maintain at least a minimum level of activity.
} 
Table 2. Properties of terrestrial bacteria with elevated temperature optima.

\begin{tabular}{llcc}
\hline $\begin{array}{l}\text { Energy Source/ } \\
\text { Electron Acceptor } \\
\text { to endproduct }\end{array}$ & \multicolumn{1}{c}{ Organism } & $\begin{array}{c}\text { Max. growth } \\
\text { temp. ( }\end{array}$ & Optimal $\mathbf{~ p H}$ \\
\hline $\mathrm{H}_{2} / \mathrm{CO}_{2}$ to $\mathrm{CH}_{4}$ & Methanothermus fervidus & 97 & 6.5 \\
$\mathrm{H}_{2} / \mathrm{CO}_{2}$ to $\mathrm{CH}_{4}$ & Methanococcus igneus & 91 & 5.7 \\
$\mathrm{H}_{2} / \mathrm{S}$ to $\mathrm{H}_{2} \mathrm{~S}$ & Thermoproteus tenax & 96 & 5.5 \\
$\mathrm{H}_{2} / \mathrm{S}_{2} \mathrm{O}_{3}$ or $\mathrm{S}$ to $\mathrm{H}_{2} \mathrm{~S}$ & Pyrodictium occultum & 110 & 6.5 \\
$\mathrm{H}_{2} / \mathrm{SO}_{4}$ to $\mathrm{H}_{2} \mathrm{~S}$ & Archeogolobus fulgidus & 92 & 7.0 \\
$\mathrm{H}_{2} / \mathrm{S}$ to $\mathrm{H}_{2} \mathrm{~S}$ & Acidianus infernus & 95 & 3.5 \\
$\mathrm{H}_{2} / \mathrm{S}$ to $\mathrm{H}_{2} \mathrm{~S}$ & Stygiolobus azoricus & 89 & 3.0 \\
$\mathrm{~S} / \mathrm{O}_{2}$ to $\mathrm{H}_{+}+\mathrm{SO}_{4}$ & Sulfolobus acidocaldarius & 85 & 3.0 \\
$\mathrm{H}_{2} / \mathrm{CO}_{2}$ to $\mathrm{CH}_{4}$ & Methanothermus sociablis & 97 & 6.0 \\
Organics $/ \mathrm{S}$ to $\mathrm{H}_{2} \mathrm{~S}$ & Pyrobaculum islandicum & 102 & 6.0 \\
Organics/Organics & Thermotoga maritima & 90 & 6.5 \\
Organics $/ \mathrm{S}$ to $\mathrm{H}_{2} \mathrm{~S}$ & Thermotoga neapolitana & 90 & 7.0 \\
Organics/Organics & Pyrococcus furiosus & 103 & 7.0 \\
Organics $/ \mathrm{SO}_{4}$ to $\mathrm{H}_{2} \mathrm{~S}$ & Archeogolobus profundus & 90 & 6.0 \\
Organics/Organics & Clostridium thermoalcaliphilum & 58 & 9.75 \\
\hline
\end{tabular}

Compiled from:

Kristjansson and Hreggvidsson (1995). "Ecology and habitats of extremeophiles." World J. Microbiol. and Biotechnol. 11: 17-25.

Schoenheit and Schaefer (1995). "Metabolism of hyperthermophiles." World J. Microbiol. and Biotechnol. 11: 26-57.

Stetter (1995). "Microbial life in hyperthermal environments." ASM News 61: 285-290.

Li, Engle, Weiss, Mandelco, and Wiegel (1994). "Clostridium thermoalcaliphilum sp nov., an anaerobic thermotolerant facultative alkaliphile." Int. J. System. Bacteriol. 44: 111-118. 


\subsection{Microbial Modes, Adaptation to Stress, and Mutation}

\subsubsection{Most bacteria can develop resistance to conditions outside the range of optimal growth.}

The capacity for adaptive response is genetically preprogrammed, and generally becomes induced upon exposure to a stressor (Straus et al., 1987). Resistance to elevated salinity, low and high $\mathrm{pH}$, temperature, and starvation is triggered in a variety of organisms when unfavorable conditions are encountered (Csonka, 1989; Foster and Hall, 1991; Slonczewski et al., 1987; Jenkins et al., 1991). Furthermore, resistance to a single stressor can induce resistance to other stressors; thus there appears to be a certain amount of coordination between resistance mechanisms that allows for cross-resistance to a variety of stress factors (Fig. 1) (McCann et al., 1991). While resistance to multiple extremes can be induced, simultaneous exposure to a variety of extreme conditions may cause greater numbers of killed bacteria than a single extreme condition alone.

\subsubsection{The rate of genotypic change can increase as a result of mutational events that are incurred by exposure to radiation.}

Genotypic change occurs at a constant rate naturally in every biological community (Freifelder, 1987). If radiation fields are encountered by both native and introduced bacteria in the repository, then these organisms will be genotypically altered at much higher rates than occur under normal conditions. In fact, it has been shown that rates of mutation increase under starvation conditions (Matin, personal communication), and nutrients in a repository environment are eventually expected to become depleted. Accumulated mutations in the presence of strong selective pressures, such as the extreme conditions that are anticipated at Yucca Mountain, could lead to significantly higher survival frequencies and altered activities of surviving microbes.

\subsubsection{Microbes can alter their surroundings, thereby increasing environmental heterogeneity.}

By secreting extracellular products, microbes necessarily change their own habitats. Secretory compounds include metabolic endproducts, capsular materials, and specialized molecules that act in signaling and play roles as receptors (Brock and 
Madigan, 1991). Since the distribution of these compounds is not necessarily homogeneous, microbes can increase the amount of heterogeneity found in a given habitat.

\section{Summary: Microbes alter their own environments and have extensive abilities to adapt to harsh conditions beyond their normal range of growth conditions.}

\subsection{Limits to Microbial Growth and Activity}

\subsubsection{Water is essential to support microbial activity.}

To illustrate microbial need for water, we introduce the microbiological use of the term "water activity" $\left(\mathrm{a}_{\mathrm{w}}\right)$ as an index of the actual availability of water for microbial use, where the $a_{w}$ of distilled water is defined as 1.0 (Brown, 1976). Brown (1976) develops the model for water activity in a thermodynamic sense as a function of the solute concentration, the activity of water and the solute, and adsorption of the solution to solid surfaces. It is not clear whether use of the $a_{w}$ term in microbiology is consistently applied as a thermodynamic parameter. However, by noting that most microorganisms require $\mathrm{a}_{\mathrm{w}}$ values above 0.9 to support active metabolism (which corresponds to $60-80 \%$ soil saturation [Atlas and Bartha, 1981]), we make the qualitative point that threshold values for microbial activity as a function of water availability can be defined and that these can be relatively high. That is, dry environments reduce total microbial activity. Note, however, that many soil microbes have structural features that allow them to thrive in desiccated environments (e.g., by using biofilms) to locally maintain elevated $a_{w}$ (Chapelle, 1993; Geesey, 1993). In desiccated environments fungi may be more active than bacterial populations; fungi have also been associated with cement corrosion (Perfettini et al., 1991).

\subsubsection{Ranges of temperature that support microbial growth and activity can vary widely among different species.}

While organisms that inhabit temperate habitats most often have growth optima in the $25-40^{\circ} \mathrm{C}$ range (mesophiles), those that are found in extreme environments often display correspondingly altered optimal growth temperatures. 
Organisms are known that are capable of growth below $0^{\circ} \mathrm{C}$ (psychrophiles) and above $60^{\circ} \mathrm{C}$ (Table 2) (Morita, 1975; Kristjansson and Hreggvidsson, 1995).

\subsubsection{It is generally accepted that the upper temperature boundary for bacterial activity is $120-150^{\circ} \mathrm{C}$.}

See Table 2. Earlier investigations reported culturing bacteria from deep-sea hydrothermal vents at temperatures up to $250^{\circ} \mathrm{C}$ (Baross and Deming, 1983). However, more recently the consensus among workers in this area is that the upper limit to bacterial growth is in the range of $120-150^{\circ} \mathrm{C}$. (Reeve, 1994).

\subsubsection{Some microbes are known to survive in high radiation fields.}

The resistance of microbes to gamma radiation varies. Bacterial spores are relatively radiation-resistant; $3-4 \mathrm{kGy}$ of irradiation is required to effect a $90 \%$ kill, while most vegetative (non-sporulated) cells require only one tenth of this dosage to effect the same percentage kill (Atlas and Bartha, 1981). However, there are species of bacteria that display much greater radiation resistance even in the vegetative state, including Micrococcus radiodurans, which can tolerate $10 \mathrm{kGy}$ of irradiation without any effect on the viable cell count (Anderson et al., 1956). It has also been shown that when they are contained in bentonite buffer material, it requires up to $1.3 \mathrm{kGy}$ of irradiation to effect a 10 -fold decrease in viability of spores of the common soil bacterium, Bacillus subtilis and the radioresistant Acinetobacter radioresistens (Stroes-Gascoyne et al., 1994).

\subsubsection{A variety of microorganisms thrive under extremely alkaline or acidic conditions.}

Most microorganisms are adapted to near-neutral $\mathrm{pH}$ habitats. However, acidophilic organisms that produce nitric or sulfuric acids, such as members of the genera Thiobacillus and Sulfolobus, typically grow at $\mathrm{pH}$ values less than 3 . Other alkalinophilic organisms require elevated $\mathrm{pH}$ ranges of 10-11 for growth (Brock and Madigan, 1991). Alkalinophiles comprise a heterogeneous group and include typical soil bacteria isolated from soils that are not particularly alkaline (Krulwich and Guffanti, 1989). Some alkalinophiles and acidophiles have been shown to be thermophilic as well, tolerating both an extreme in $\mathrm{pH}$ and elevated temperatures (Table 2) (Li et al., 1993). This may well have implications for the stability of the 
typically alkaline cement components of a repository, which may be susceptible to the corrosion by these alkaline-tolerant organisms.

Summary: Microbial activity can be limited by insufficient water, temperature extremes, ionizing radiation, and $\mathrm{pH}$ extremes. These specific boundaries vary, however, depending on the microbial species and habitat under consideration.

\subsection{Re-Establishment of Microbial Activity}

2.4.1. Both spores and dormant cells are capable of reviving to an active, growing state if conditions become conducive to activity or growth.

Dormancy is most often a response to unfavorable environmental conditions and can result in metabolic arrest or the formation of spores. Many species of soil microbes form resistant spores when conditions become unfavorable for growth; these can undergo exposure to extremely harsh conditions and still remain viable. Both spores and cells in metabolic arrest are capable of renewing growth if conducive conditions arise. In fact, it is generally acknowledged that environmental organisms that occur in low-nutrient habitats are especially adapted to reactivate growth by immediately taking advantage of nutrients when they appear.

\subsubsection{After subsurface areas are subjected to heat stress, total numbers of organisms decrease and microbial community structures probably shift, with spore-forming organisms predominating.}

Direct microscopic counts of organisms isolated before and after steam treatment of a subsurface region that raised temperatures up to $94^{\circ} \mathrm{C}$ for prolonged periods show that total numbers of organisms declined one to two orders of magnitude (Krauter and McQueen, 1995). Fatty acid analyses of organisms isolated before and after treatment show a distinctly altered pattern of predominating fatty acids. While this shift in fatty acids could be due to adaptation of predominating organisms to elevated temperatures (Suutari and Laakso, 1994), similar types of organisms displayed nearly identical fatty acid patterns before and after heat 
treatment. Also, when fatty acid profiles were used to classify many of the isolates, it was found that while Pseudomonas bacteria dominated the microbial community before heat treatment, spore-forming Bacillus were predominant following heat exposure (Krauter and McQueen, 1995). These observations support the supposition that heat-tolerant organisms are extant in subsurface areas, and when conditions arise that discourage the growth of heat-sensitive members of a microbial community, the heat-resistant species will become dominant.

\title{
2.4.3. Bacteria can move both actively and passively through various geologic media using a variety of mechanisms.
}

Both spores and dormant, dead, and vegetative organisms can move long distances by passive transport with air currents, even through fractures. They also enter the atmosphere as aerosols, transported on water droplets. Microorganisms can disperse on soil and dust particles that often move vertically from the earth's surface. Bacteria inhabiting ground and pore waters can move with the prevailing water flux, and on moist surfaces many organisms can actively use motility mechanisms to tra verse distance. It is therefore probable that even if a given region is sterilized, at some later point it can become recolonized by bacteria migrating from surrounding areas.

\begin{abstract}
Summary: After cessation of biological activity due to exposure to extreme environmental conditions, dormant cells can revive and the region may be repopulated by migration of organisms when conducive conditions arise.
\end{abstract}

\subsection{Chemical Consequences of Microbial Metabolism}

2.5.1. Microbial activities alter water chemistry in a manner that is distinct from standard abiotic chemical reactions; however, biogenic alterations to water chemistry may be amenable to modeling.

Microbial activities alter water chemistry through catabolic and anabolic metabolism. At least some microbial affects are amenable to modeling. For example, a numerical model that describes a particular biodegradative reaction has been for- 
mulated for a very tightly constrained system (Tompson et al., 1994); rates of cement degradation and resulting chemical changes (e.g., $\mathrm{pH}$ ) could be similarly modeled. However, for the purpose of modeling the comprehensive perturbed Yucca Mountain environment, a broader range of microbially mediated chemical processes must be simulated. Microbially mediated chemical processes are complex enough that a simple assignment of a reaction rate will not be sufficient to describe the chemical evolution of a geological setting that includes microbial activity. However, some general observations can be made. Chemical modeling programs that are presently being used within the Yucca Mountain Project (e.g., EQ3/6, Wolery 1992a, 1992b) use standard laws of thermodynamics to predict water chemistry. To date, the chemistry of microbially mediated chemical alterations have not been incorporated into these chemical modeling programs. Minor changes to the database may accommodate the simulation of some chemical effects of microorganisms on the repository environment. Other aspects of modeling microbially mediated chemical processes (e.g., colony growth, adaptation) are expected to require the development of new models that can be used in concert with EQ3/6 or other abiotic chemical modeling codes.

\subsubsection{Anabolic metabolism generates biomass, the raw materials of which must originate from exogenous sources.}

The elements required to build cellular components are supplied by compounds in the surrounding medium. Intracellular reaction pathways alter and synthesize these building blocks to generate required proteins, carbohydrates, and nucleic acids required for the generation of new cells.

\subsubsection{Oxidation of reduced compounds results in a general decrease in $\mathrm{pH}$ of the surrounding aqueous environment.}

Oxidation of reduced compounds drives the formation of high-energy biochemical compounds, organic acids, and protons. Fermentations directly produce organic acids as endproducts, as do acetic acid bacteria, which oxidize carbohydrates and alcohols to organic acids (Table 1). Complete oxidation of both organic and inorganic compounds generates protons that are exported to the surrounding media by bacteria, creating a proton gradient across the cell membrane. Dissipation of this gradient by subsequent intake of protons is used to drive the formation of biochemical energy. Thus, centralized microbial metabolism results in a lowering of the $\mathrm{pH}$ of the surrounding media (Stanier et al., 1976; Lehninger et al., 1993). 


\subsubsection{Hydrogen gas can be produced or consumed by different types of bacterial metabolic processes.}

Molecular hydrogen is formed through the action of the enzyme hydrogenase, which disposes of excess electrons in anaerobic systems by combining them with protons. However, hydrogenases can also act in reverse to consume hydrogen and extract the electrons in a more utilizable biochemical form. Gaseous hydrogen is also liberated in fermentations of many organic compounds, including starch, proteins, and hydrocarbons (Bachofen, 1991). Hydrogen is consumed by methanogens, which utilize it to reduce carbon dioxide, and by hydrogen bacteria, which use it as a electron source (Stanier et al., 1976).

\subsubsection{The biogeochemical cycles of nitrogen and sulfur perform similar environment-dependent redox transformations.}

In the biogeochemical cycles of nitrogen and sulfur (Fig. 2), the most oxidized species are generated under oxic conditions; both elements are reduced under anoxic conditions (Bachofen, 1991). Oxidized nitrates and sulfates are most easily incorporated into biological systems and support growth; however, they are easily lost from natural systems through leaching. On the other hand, reduced forms are gaseous and can escape a porous system, such as the repository environment, through diffusion.

\subsubsection{Oxidation and reduction of nitrogen compounds occur through the activity of microorganisms.}

Two groups of nitrifying bacteria are responsible for using reduced nitrogen compounds as electron donors, one of which converts ammonia to nitrite, and a second that utilizes nitrite to form nitrate (Table 1, Fig. 2). Nitrate can be reduced either to ammonia or to nitrogen gas. At alkaline $\mathrm{pH}$, ammonia is volatile.

Denitrification produces various gaseous nitrogen oxide intermediates with gaseous nitrogen as a final product from nitrate. Of the various microorganisms known to denitrify, most reduce nitrate only under anoxic conditions. Under oxic conditions, a small group of microorganisms mediate the fixation of gaseous nitrogen to nitrate and ammonia which is used to build cellular compounds; bacterially mediated nitrogen fixation accounts for over $90 \%$ of total nitrogen fixation. Since all other biological organisms are dependent on fixed sources of nitrogen, bacterial nitrogen 
fixers are wholly responsible for supplying the earth's biota with nitrogen for use in the construction of proteins, nucleic acids, and other essential cellular components (Stanier et al., 1976; Bachofen, 1991).

\subsubsection{Microbial reduction of oxidized sulfur compounds produces hydrogen sulfide.}

Hydrogen sulfide is produced by microbial activity through use of oxidized sulfur compounds as electron acceptors, using organic compounds or hydrogen as electron donors (Table 1, Fig. 2). Anaerobic decomposition of proteins yields methylsulfide and dimethylsulfide, which are reduced to hydrogen sulfide under anoxic conditions, and oxidized to sulfate in aerobic conditions. Produced hydrogen sulfide precipitates metal cations, and can thus act to sequester trace elements for microbial growth. Furthermore, produced hydrogen sulfide is toxic to most organisms, including sulfate-reducing organisms, at high concentrations (Bachofen, 1991; Atlas and Bartha, 1981). Sulfate-reducing bacteria play a major role in metal corrosion by consuming hydrogen and causing the production of metal sulfides (see Sec. 2.6.2; Geesey, 1991; Lee et al., 1995).

\subsubsection{Sulfuric acid can also be produced by bacteria.}

Sulfur bacteria use reduced sulfur compounds, such as elemental sulfur and hydrogen sulfide, as sources of electrons and oxidize them to sulfate, thereby producing sulfuric acid (Table 1, Fig. 2) (Brock and Madigan, 1991):

$$
\begin{aligned}
& \mathrm{H}_{2} \mathrm{~S}+2 \mathrm{O}_{2} \rightarrow \mathrm{SO}_{4}{ }^{2-}+2 \mathrm{H}^{+} \\
& \mathrm{S}^{0}+2 \mathrm{H}_{2} \mathrm{O}+\mathrm{O}_{2} \rightarrow \mathrm{SO}_{4}{ }^{2-}+4 \mathrm{H}^{+} \\
& \mathrm{S}_{2} \mathrm{O}_{3}{ }^{2-}+\mathrm{H}_{2} \mathrm{O}+2 \mathrm{O}_{2} \rightarrow 2 \mathrm{SO}_{4}{ }^{2-}+2 \mathrm{H}^{+}
\end{aligned}
$$

Therefore, sulfur-containing cement formulations should be avoided in the design of the repository. Additionally, some members of this class of microorganisms, for example the Sulfolobus, have very high temperature optima and are normal inhabitants of hot springs (Kristjansson and Hreggvidsson, 1995). Thermophilic sulfur bacteria could act to compromise the integrity of a repository even at elevated temperatures. 


\subsubsection{Microorganisms can produce and consume carbon dioxide and carbon monoxide.}

Carbon dioxide is produced as an end-product of microbial metabolism through the complete oxidation of organic compounds in the presence of oxygen, sulfate, or nitrate as an electron acceptor (Table 1, Fig. 2). It is also released during fermentative metabolism. Carbon dioxide is consumed by autotrophic organisms, which are capable of utilizing it as a carbon source. It is also used as a terminal electron acceptor by methanogens generating methane, and acetogenic bacteria producing organic acids (Stanier et al., 1976). Methanogens also produce carbon monoxide, while both methanogens and acetogens are capable of using carbon monoxide as an electron acceptor, and a few microorganisms are able to use carbon monoxide as a carbon and energy source (Bachofen, 1991). Thus, biogenic production of these gases can serve both to promote further microbial metabolism and affect mineralization of carbon through the abiotic formation of calcium carbonates.

\subsubsection{Bacteria can both oxidize ferrous iron and reduce ferric iron.}

Acidic conditions can arise as a result of these reactions.

Ferric iron $\left(\mathrm{Fe}^{3+}\right)$ can be used as a terminal electron acceptor by many anaerobic bacteria. This is the major mechanism by which iron is solubilized in nature. Subsequent exposure of the resulting reduced ferrous iron $\left(\mathrm{Fe}^{2+}\right)$ to oxygen regenerates the ferric state and causes complexation with hydroxide ions, precipitating the iron and generating acidic conditions (Brock and Madigan, 1991). Iron-oxidizing bacteria, most notably those of the genus Thiobaccillus, use reduced ferrous iron as a source of electrons, converting it to ferric iron, which is a powerful oxidizing agent that can, in turn, oxidize other metals. This occurs after dissolution of pyrite $\left(\mathrm{FeS}_{2}\right)$, which generates ferrous ions that are bacterially oxidized, forming ferric iron and sulfuric acid. The continuing reaction is fueled by the resulting $\mathrm{Fe}^{3+}$ acting as an oxidant on more pyrite, with increasing amounts of sulfuric acid production accompanying pyrite dissolution:

$$
\mathrm{FeS}_{2}+14 \mathrm{Fe}^{3+}+8 \mathrm{H}_{2} \mathrm{O} \rightarrow 15 \mathrm{Fe}^{2-+}+2 \mathrm{SO}_{4}{ }^{2-}+16 \mathrm{H}^{+} \text {. }
$$

Thiobacilli can analogously dissolve copper and gold sulfides, solubilizing these metals to their corresponding oxidized cations (Brock and Madigan, 1991). These organisms are routinely used in the mining industry for leaching metals out of low-grade sulfide ores, with concomitant generation of sulfuric acid. They are 
widespread in their distribution, and their activities can contribute to metal corrosion directly and also through the oxidizing action of generated $\mathrm{Fe}^{3+}$ and produced acid. Thermophilic iron oxidizers, whose temperature optima are $50^{\circ}$ to $90^{\circ} \mathrm{C}$, are known to occur (Moffat, 1994). Therefore, even at the elevated temperatures expected to be encountered within the repository, iron oxidation could take place.

\subsubsection{Solubilization of metals is not limited to direct oxidation by the use of reduced metal ions as electron donors.}

Solubilization of metals can also result from a lowering of the $\mathrm{pH}$ by acidproducing organisms to create oxidizing conditions. Fermentative organisms use a wide variety of reduced organic substrates as both carbon and electron sources. Generally, these substrates are partially oxidized, producing organic acids and alcohols (Table 1). Hydrochloric acid can also be produced by combining chlorine ions, if present, with biogenic protons (Pope et al., 1982). Many fermentative organisms are normal inhabitants of soils and deep subsurface environments.

\subsubsection{A number of other microbially mediated metal biotransformations can solubilize or precipitate metals.}

A number of microbial enzymatic systems result in the specific reduction of metal cations, in some cases resulting in bacterial metal toxicity resistance. Reduction of mercuric ions to elemental mercury (Summers, 1986), hexavalent chromium to the trivalent state (Cervantes, 1991), selenate to selenite or elemental selenium, and gold and silver cations to lower oxidation states has been reported (Lovley, 1993). Biogenically produced hydrogen sulfide precipitates metal ions as metal sulfides.

Metal cations may also act as alternative electron acceptors for select anaerobic metabolic pathways, resulting in their reduction (e.g., uranium, copper) (Lovley, 1993). Alternatively, insoluble metal oxides have also been shown to act as electron acceptors, resulting in their dissolution under anaerobic conditions; this is compounded by the action of organic acid metabolites (Francis and Dodge, 1988). Anaerobic bacteria have also been reported to use elemental metals as electron donors, resulting in their oxidation (Lorowitz et al., 1992). 
Summary: The modes of microbial metabolism are extremely diverse, using substrates and generating products that have significant effects on geochemical reactions. Microbial metabolism has also been shown to cause corrosion of building materials. None of these reactions are at present modeled using the EQ3/6 chemical modeling code. Some of these reactions may be accounted for through slight modifications of the GEMBOCHS database. However, other reactions, as well as the ability to model the evolution of the microbially mediated chemistry as a function of environmental parameters (such as temperature and $\mathrm{pH}$ ), will require the development of new codes that can be coupled with the EQ3/6 code.

\subsection{Other Microbial Processes}

2.6.1. Biofilms allow the growth of microbes in otherwise inhospitable environments.

Bacterial colonization of surfaces generally entails the formation of biofilmembedded communities (Fig. 3). Biofilms are primarily composed of heteropolysaccharides (i.e., sugar polymers) secreted by bacteria, forming a matrix or slime layer on solid surfaces in which bacteria become embedded (Shaw et al., 1985). Biofilms aid in capturing and retaining moisture and organic and inorganic nutrients, thereby creating microenvironments where internal conditions are altered from the external environment. Even within a given biofilm, conditions are heterogeneous; for example, the region closest to the colonized surface is often anoxic, while the surface of the biofilm exposed to the surrounding media may be completely oxic (Lee et al., 1995). The relative immobility of the bacteria within the biofilm allows them to form spatially defined relationships.

2.6.2. Microbially mediated corrosion (MIC) of metals is an electrochemical process.

The most widely described MIC mechanism specifies that microbes colonize a metal/solution interface through the formation of a biofilm that leads to the physical separation of anodic and cathodic sites (Fig. 4). Occlusion of the metallic 
surface by cells and associated slime reduces accessibility of oxygen to the metal surface, leading to the formation of an electrochemical cell. Depletion of the cathodic reactant (for example, oxygen) under the biofilm promotes anodic dissolution of the metals in this area, generating acidification through hydrolysis of metal cations, increasing the concentration of aggressive ions (such as chloride), and fostering oxidative dissolution of metal sulfides (Geesey, 1991). The rate-limiting step for biocorrosive activity may be the consumption of hydrogen by sulfatereducing bacteria, which "depolarize" the cathode, thereby accelerating corrosion (Lee et al., 1994).

The localized environment within and beneath the biofilm is very complex because of multiple biochemical reactions and the generation of metabolic endproducts through bacterial activities. The process does not appear to be highly dependent on the colonization of metal surfaces with a large number of bacteria; as few as one million organisms per square meter can cause metal damage (Little et al., 1992).

\subsubsection{Microbial activity can affect metal complexation and transport.}

Both microbial anabolic products and organic degradation endproducts can form metal complexing agents. Microorganisms are known to harbor specific metalbinding molecules, and catabolic endproducts such as organic acids and alcohols, as well as other compounds, have been shown to efficiently bind metals (Table 3) (Birch and Bachofen, 1990). Complexing agents could act to either facilitate or inhibit transport of radionuclides. Transport might be encouraged by increasing the degree of solubility or providing a colloidal particle for binding. For example, a number of bacteria release siderophores to scavenge $\mathrm{Fe}^{3+}$ from the surrounding media and supply it to the cell (Nielands, 1981). Some siderophores have been shown to complex $\mathrm{Ga}^{3+},{ }^{91} \mathrm{In}$, as well as Pu and several other metals (Bulman, 1978; Rogers et al., 1980). Metallothioneins are low-molecular-weight sulfur-containing proteins that are produced in response to heavy-metal exposure and bind various metals (Kagi and Kojima, 1987). Cell wall, membrane, and capsular biofilm (polysaccharide) materials have also been found to be efficient metal biosorbants (Gadd, 1990). Unspecified complexing agents that are produced by some soil bacteria have been shown to act as uranium and thorium ligands (Premuzic et al., 1985). Alternatively, transport might be inhibited by adsorption to a stable matrix, or via precipitation. 
Table 3. Complexing actions of microbial products.

\begin{tabular}{|c|c|}
\hline Products of microbial origin & Action \\
\hline Tricarboxylic acids & Complexation of manganese \\
\hline Citric acid & $\begin{array}{l}\text { Formation of complexes with } \\
\text { plutonium }\end{array}$ \\
\hline \multirow[t]{2}{*}{ Catechol } & Various actinides \\
\hline & $\begin{array}{l}\text { Implicated in the uptake of } \\
\text { germanium into microbial cells }\end{array}$ \\
\hline $\begin{array}{l}\text { Oxalate, salicylate, acetate, lactate, } \\
\text { pyruvate, and polypeptides }\end{array}$ & Solubilized uranium \\
\hline $\begin{array}{l}\text { Uncharacterized low-molecular-weight } \\
\text { anions found in leachates from seepage } \\
\text { trenches }\end{array}$ & $\begin{array}{l}\text { Solubilized technetium, cobalt, } \\
\text { uranium }\end{array}$ \\
\hline $\begin{array}{l}\text { Uncharacterized low-molecular-weight } \\
\text { ions produced by Bacillus thuringiensis } \\
\text { in molybdenum-deficient medium }\end{array}$ & Complexed molybdenum \\
\hline $\begin{array}{l}\text { Uncharacterized organic ligands in } \\
\text { saline and alkaline lake water }\end{array}$ & $\begin{array}{l}\text { Maintained elevated concentrations of } \\
\text { the normally insoluble thorium, } \\
\text { protactinium, uranium, and } \\
\text { plutonium ions }\end{array}$ \\
\hline Siderophores & $\begin{array}{l}\text { Bind gallium, chromium, aluminum, } \\
\text { scandium, indium, and plutonium }\end{array}$ \\
\hline Metallothioneins & $\begin{array}{l}\text { Bind cadmium, copper, zinc, mercury, } \\
\text { lead, strontium, indium, cerium, and } \\
\text { palladium }\end{array}$ \\
\hline $\begin{array}{l}\text { Polysaccharides, membrane and } \\
\text { cell wall }\end{array}$ & $\begin{array}{l}\text { Efficient non-specific adsorption of } \\
\text { metals }\end{array}$ \\
\hline
\end{tabular}

After Birch and Bachofen (1990). 


\subsubsection{Biotransformation of radionuclides}

Many microorganisms are capable of altering the ionic state of various radionuclides through a number of biochemical mechanisms, thereby affecting downstream geochemical interactions (Francis, 1990). For example, it has been shown that soluble $\mathrm{U}^{6^{+}}$can be reduced to insoluble $\mathrm{U}^{+4}$ by both iron- and sulfatereducing microbes (Lovley and Phillips, 1992; Lovley et al., 1991).

\subsubsection{Microorganisms may act to affect flow rates and thereby alter the transport of radionuclides out of the near field repository environment.}

The possible growth or activity of microorganisms in rock fractures as a result of altered conditions after waste emplacement could potentially affect the hydrological properties of the repository horizon. It has already been shown that both starved and vegetative cells reduce permeability in artificial rock cores (MacLeod et al., 1988). This has been the basis of a system for enhancing oil recovery from low-permeability rock strata (Lappin-Scott et al., 1988).

Summary: Microorganisms can form their own environments, corrode as well as complex and transform metals, and affect the permeability of rock strata. These properties could have significant effects on their survival, level of activity, and overall impact on the integrity of a geological repository. 


\section{Microbial Considerations from a Repository Perspective}

\subsection{General Considerations}

\subsubsection{General assessment of the potential impact of microbes.}

Conditions anticipated upon waste emplacement in the proposed Yucca Mountain repository will include extreme heat, desiccation, and possibly high levels of ionizing radiation. The initial presence of extreme conditions within the repository may not completely preclude microbial activity; even if general conditions extend beyond those able to support microbial activity there may be microenvironments in which environmental extremes are mitigated. In any case, eventual repopulation of the near-field environment is anticipated as overall repository conditions become amenable to microbial activity. We may expect that thermophiles will be extant within the native or introduced microbial communities at Yucca Mountain. Microbial populations may acidify and otherwise alter the porewater chemistry of the near-field repository environment, as well as directly affect the corrosion of repository waste packages, and produce gases that generate pressure. The degradation of materials and the consequent alteration of the aqueous chemical environment, with accompanying effects on repository performance, will depend on the presence of adequate nutrients to maintain at least a minimum level of activity.

\subsubsection{Nutrient requirements.}

In a repository environment, required nutrients would have to be supplied by either the natural environment or by introduced materials. Dead bacteria can also act as a nutrient supply for viable organisms. Almost all natural environments are either nutrient-poor, or nutrients are unavailable for utilization by microorganisms (oligotrophic). Native organisms have adapted to survive these conditions, growing very slowly, if at all. Given that other conditions (e.g., heat, water, and radiation) are amenable to microbial activity (Fig. 5), then one might expect an increase in microbial populations as the introduced materials are utilized, followed by the return of an oligotrophic, slow-growth environment as introduced nutrients become depleted.

It may therefore be possible to model the totality of microbial growth by calculating the total amounts of available nutrients, as has been attempted for the Swiss and Canadian repositories (Stroes-Gascoyne, 1989; McKinley and Hagenlocher, 
1993). These estimates necessarily include broad assumptions that can only be resolved by investigation of fundamental parameters (e.g., determination of in situ kinetics, nutrient cycling, and abiotic geochemical contributions). However, such models could help to define the total quantity and duration or window during which microbial biomass may be generated.

\subsubsection{Temperature.}

Maintenance of hot $\left(>120^{\circ} \mathrm{C}\right)$ and dry conditions (bounding relative humidity is yet to be adequately established) for an extended period is expected to prevent all biotic activity in affected areas (Reeve, 1994). However, microenvironments may exist in which organisms can maintain activity even in very inhospitable habitats (see below). Extant organisms may die in heat-effected regions, sporulate, or otherwise undergo metabolic arrest when exposed to hot and dry conditions, and would not be expected to appreciably contribute to alterations in the chemical environment when dormant, dead, or sporulated.

\subsubsection{Heterogeneity in the repository.}

Microenvironments are anticipated in which conditions vary greatly from average observed conditions. Natural environments are generally extremely heterogeneous, and repository construction will produce further chemical, hydrological, and thermal heterogeneity. It is also probable that the distribution of oxygen and radiation within the repository will not be homogeneous. For example, ventilation shafts, crevices, and roadbeds are expected to maintain altered conditions from that of the repository as a whole. Microbes can take advantage of microenvironments and thrive in areas that best suit their needs. In addition, biofilms can create microenvironments. Therefore, the potential exists for microbial strains to survive multiple extreme conditions like those expected to be encountered in a repository facility.

\subsubsection{Microbes are expected to repopulate the environment near the waste package after inhospitable conditions dissipate.}

Although conditions in the drift may exclude microbial activity at various times after waste emplacement, these conditions are expected to gradually dissipate through the near-field. Therefore, despite the inhospitable conditions close to the 
repository, at some undetermined distance from the drift, microbes will be able to maintain and possibly achieve optimal activity if adequate nutrients are available. Active populations could migrate back toward the repository when temperatures cool and water radiates back to the near-field environment (Fig. 6). Further, zones of decreased radiation could cause mutation rates that encourage the growth of organisms that are ideally adapted to extreme conditions.

3.1.6. Repository temperatures will eventually cool below the boiling point, allowing re-entry of water into the near field.

Re-migration of water will bring with it both nutrients and microbes, thereby recreating conditions conducive for microbial activity and allowing the germination of spores (Fig. 6).

\begin{abstract}
Summary: While initial repository conditions are expected to be extreme, some microbes may survive in a dormant state or retain activity in microenvironments. Dormant cells are expected to revive and the near-field environment will eventually become repopulated when conducive conditions are regained. Since microbial growth is dependent on specific resources supplied by the environment, total production of microbial mass may be estimated through the use of computer modeling.
\end{abstract}

\title{
3.2. Degradation of Materials
}

3.2.1. Microorganisms have been shown to seriously compromise the integrity of metallic structures, conduits, and machinery.

Bacterially generated metal penetration can result in dissolution of 0.5 to $>2 \mathrm{~cm}$ of carbon steel per year (Little et al., 1992). Bacterially mediated reactions have been shown to corrode a variety of metals, metal-containing ores, and metal alloys (Borenstein, 1994). Microbially induced corrosion is an enormous problem in a number of industries that rely on the use of metals and cause extensive loss of 
capital expenditures. Precise mechanisms and interactions that cause microbially induced corrosion have not been completely elucidated. However, it is known that both bacterially mediated acid production and sulfate reduction are involved, and this type of metal corrosion is associated with the presence of nitrate, sulfate, and chloride ions (Pope et al., 1982). Microbially facilitated corrosion could significantly affect repository components-both tunnel construction elements and waste containers. It is conceivable that microbes could exist inside the waste package itself where protected locally from radioactive and thermal radiation, or from sporulated microbes. Activity, however, would be limited by the presence of water. Thus, vestigial water in the waste package could allow the initiation of microbially mediated corrosive reactions from the inside of the containers, after dissipation of high temperatures and radiation to conditions within the limits of microbial activity.

\subsubsection{A number of organisms are capable of causing the dissolution of concrete through leaching of calcium and other alkaline binding materials.}

These organisms are known to cause serious damage to sewer lines, buildings, and monuments, and could play an important role in undermining the infrastructure of a repository (Fig. 7). In environments where reduced sulfur compounds are present, such as sewers, the production of sulfuric acid by sulfur oxidizing bacteria causes extensive cement degradation. In environments where reduced sulfur compounds are limiting, such as on buildings, nitric acid-producing nitrifying bacteria have been found to play a role in concrete degradation (Diercks et al., 1991). They have been found even in extreme environments such as the inner wall of a geothermal cooling tower (Rogers, 1995), and they are natural inhabitants of soils. Concrete can also be corroded by gluconic, malic, and oxalic acids produced by fermentative bacteria, which are normal soil inhabitants (Sand and Bock, 1991). Fungi have also been implicated in these processes and they therefore may be a relevant factor to consider in assessing corrosion of repository components (Perfettini et al., 1991). 
3.2.3. Preliminary evidence shows that bacteria may promote dissolution of glass by producing acidic conditions, promoting the chelation of glass elements with secreted metabolic endproducts, and altering the redox states of glassincorporated metals.

Colonization of glass surfaces by microorganisms accompanied by pitting beneath bacterial colonies or biofilms has been reported (Thorseth et al., 1992; Staudigel et al., 1995). It has been proposed that this glass dissolution may be caused by microbially generated alterations in the local $\mathrm{pH}$, since rates of glass breakdown have been shown to be significantly affected by $\mathrm{pH}$ (Knauss et al. 1990; Thorseth et al., 1992). Bacterially secreted metabolic endproducts such as organic acids complex and solubilize metals through chelation; silicon and aluminum were mobilized from a quartz+feldspar sandstone aquifer by such activity (Hiebert and Bennett, 1992). The occurrence of fermenting organisms in the subsurface has been correlated with high concentrations of organic acids in surrounding pore waters (McMahon et al., 1991, 1992); this could contribute to $\mathrm{pH}$-induced dissolution of waste packaging material and chelation of structurally important elements of glass containment in a repository. Borosilicate waste glasses contain many elements, such as iron and manganese, that undergo redox reactions that can be microbially mediated. It is therefore likely that microbes can also effect glass dissolution through the same mechanisms that alter minerals (Barnes and Cochran, 1993; Lovley et al., 1990). Observed increased bacterial activity induced by the presence of glass surfaces has led to the supposition that glasses may be preferentially attacked by microbes to release essential trace elements for microbial growth, such as magnesium (Loosdrecht et al., 1990).

\begin{abstract}
Summary: Microorganisms have the capacity to cause the dissolution of metal, cement, and ceramic materials. They thus could pose a threat to the performance of a nuclear waste facility containing structural elements composed of these materials.
\end{abstract}




\subsection{Alteration of Near-Field Chemistry}

\subsubsection{Nutrient supply, rate of nutrient transport, and the composition of the repository microbial community will govern the types of metabolic activities that occur.}

Microorganisms vary widely in the types of metabolic activities they can potentially perform (see above). Historically they have been classified according to metabolic type. One would expect to find native subsurface microbes in the repository environment. Microbial communities have been isolated from a variety of deep subsurface environments, and ongoing work has already identified some of the native microbiota in the Yucca Mountain region (Russell et al., 1994; Haldeman et al., 1993; Haldeman et al., 1994; Haldeman and Amy, 1993).

It is expected that non-native bacteria will be introduced to the repository through the activities associated with drift construction and operation. Bacteria are ubiquitous in distribution and are known to attach to and transport on various surfaces; they can also disperse through the air or water (Atlas and Bartha, 1981). Thus, microorganisms will be introduced into the repository by transport on workers, construction equipment, construction materials, the ventilation system, and drilling fluids.

The potential reactions carried out by bacteria are dictated by both innate metabolic type, and the conditions to which they are exposed. The types of metabolic activities that are possible are governed by the availability of substrates; for example, sulfate reduction with the concomitant generation of hydrogen sulfide is only possible if sulfate-reducing bacteria are present and sulfate is available to this class of organisms. Presumably, native microbes that are currently present have or have had adequate resources. The establishment of introduced bacteria will likewise be dependent on adequate nutrient supplies and their rates of adaptation to the repository environment.

Native microorganisms may be better adapted to the oligotrophic conditions present in the repository horizon. Therefore it is important to assess the evolution of the repository as a nutrient system over time, because some microbes may be able to compete more effectively for introduced substrates. 
3.3.2. Microbial production of gaseous compounds may result in the generation of pressures that could compromise repository containment.

Consumption of organic materials produces carbon dioxide and methane, and other biotic processes generate hydrogen, hydrogen sulfide, nitrogen, and carbon monoxide. Microbial gas production, like other microbial activities, is subject to the availability of appropriate nutrients. The porosity of the surrounding geologic media may also enable dissipation of biotic gas generation. However, the buildup of biogenic gaseous pressure has recently become an issue of concern in the design of the Canadian repository, and could possibly compromise the integrity of the Yucca Mountain facility as well (Stroes-Gasgoyne, 1994 and personal communication).

\begin{abstract}
Summary: The microbial community in the near-field environment will include both native and introduced microorganisms. Their effects on the repository will depend on their metabolic capabilities, the availability of appropriate nutrients, and the physical properties of the surrounding geologic media.
\end{abstract}

\title{
3.4. Radionuclide Transport
}

\subsubsection{Bacteria might facilitate transport of radionuclides out of the near-field environment.}

Biofilm materials can bind metals; the long chains of charged sugar units that compose the biofilm matrix bind metal ions and can perhaps act as colloidal agents in their transport. Bacterial cell walls, composed of alternating N-Acetyl glucosamine and N-Acetyl muramic acid residues, have also been found to bind metals (Francis 1990). Outer membranes contain embedded lipopolysaccharide or teichoic that have long-chain polysaccharide components, giving the outer surface of bacterial cells a net negative charge, and also providing binding sites for charged metal or radionuclide species (Gadd, 1990; Stanier et al., 1976).

These binding sites could act as transport mechanisms as cells (alive or dead) or bits of biofilm are transported in the pore water. Binding to a colloidal, such as a 
cell or a biofilm fragment, can decouple the transport of a radionuclide into the accessible environment from its solubility in the absence of non-colloidal materials.

\subsubsection{The transport effects of biotransformations depend on surrounding abiotic factors.}

While bacteria are able to carry out alterations in the oxidation states of a number of metals, the fate of reduced (or oxidized) products depend on the surrounding chemical environment. For example, various types of bacteria reduce soluble hexavalent chromium to the trivalent form, which precipitates as a hydroxide at neutral $\mathrm{pH}$ (Cervantes, 1991). Some bacteria are also known to convert soluble divalent mercury to the elemental form, which is volatile under normal atmospheric conditions, but under altered partial gas pressures may coalesce as a solid/liquid phase (Brunke et al., 1993).

\subsubsection{Microbial growth may block fractures and affect hydrology.}

Migration of water through the tuff as a result of thermal radiation and other factors could mobilize potential nutrients, resulting in microbial growth in fractures. This could have an effect on the hydrological properties of the geological media (MacLeod et al., 1988) by changing fracture apertures and matrix porosity.

\section{Summary: Bacterial communities in a repository environment may affect the general hydrological properties of the horizon and the mobilization (or demobilization) of radionuclides.}




\section{Conclusions}

The issues presented in this document (Part I) outline the outcome of discussions held during the Workshop on Microbial Activity at Yucca Mountain in Lafayette, CA. It is clear, based on the fundamental principles of microbial behavior and growth, that both indigenous and introduced microbes will be present in an excavated geological radioactive waste repository. In addition, microbial activity will respond in a complex manner to waste-induced perturbations in the system. For example, elevated temperatures with concomitant decrease in water availability are expected to severely depress microbial activity; however, select groups of microorganisms will probably survive and others will remigrate into the near-field as temperatures decrease. Nutrient availability, governed by both abiotic and biotic factors, will ultimately dictate the types and extent of microbial alterations to the chemical environment. Radioactive flux could conceivably generate microorganisms with increased potential to both survive and impact the repository facility.

Potentially deleterious impacts of microbial activity on the radioactive waste repository environment were estimated. It was determined that microbes could:

(1) Compromise the integrity of waste packages.

(2) Modify water chemistry outside the bounds predicted by abiotic chemical calculations.

(3) Alter the rate of radionuclide transport from breached waste packages.

Conclusions reached for estimating microbial impacts on the YM facility may also be applied to any waste deposition scenario, including temporary above-ground waste impoundment.

Potentially relevant issues summarized in this report clearly transcend the boundaries of individual tasks within the Yucca Mountain Project. Thus, we conclude that an coordinated effort should be made across the boundaries of Task and Technical Area within the Yucca Mountain Project, to address and bound the influence of microbial activities that may affect the long-term integrity of a radioactive waste repository. As a result of this conclusion, we have compiled a second part to this report.

The second part (Part II) describes an approach that uses a suite of complementary methods (experimental, analytical, and modeling) as well as the global perspectives that can assist the interaction between tasks to attain firm 
findings, diminish duplication of effort, and economize time and expenditures. Part II is divided into sections that directly address the three issues listed above. This general approach is applicable to other waste-deposition schemes; since microbial life is ubiquitously distributed, the effects of microbial activities can potentially impact the containment of nuclear waste in any environment. 


\section{Glossary}

acetogen

activity

adaptation

aerobe

anabolism

anaerobe

anoxic

autotroph

biofilm

capsule

catabolism

dead

dormant
Also known as acetic acid bacteria, a group of bacteria that incompletely oxidize sugars and alcohols to organic acids.

Carrying out energy-deriving reaction pathways and responding to alterations in environmental conditions; does not require cell growth.

Physiological change that occurs in response to alteration of environmental conditions; generally the response renders the organism better able to function in the changed environment.

Organisms that require molecular oxygen $\left(\mathrm{O}_{2}\right)$ as the terminal electron acceptor.

The biochemical processes involved in the synthesis of cell constituents from simpler molecules.

Organisms that use oxidized compounds other than oxygen as a terminal electron acceptor.

Oxygen-free.

Organisms that use carbon dioxide as their sole source of cellular carbon.

A group of bacteria that are enveloped by capsular polysaccharides that have been secreted by the embedded cells.

A layer of polysaccharide that is secreted to the exterior of the cell in some bacteria.

The biochemical processes involved in the breakdown of organic compounds.

Exhibiting cessation of metabolic activity, incapacity for revival, and further cell division.

Exhibiting cessation of metabolic activity with the potential for revival under conducive conditions. 
fermentation

genotypic

growth

growth optima

heterotroph

hyperthermophile Organisms that grow optimally in temperatures above $80^{\circ} \mathrm{C}$.

lithotroph

mesophile

metallothioneins

methanogen

oligotrophic

oxic

polysaccharide

psychrophile

selective pressure

Energy-generating reaction pathways that use reduced organic compounds as both electron donors and acceptors; energy generation whereby part of a reduced organic compound is oxidized and part is reduced.

Refers to the genetic (DNA) complement of an organism.

Production of daughter cells from a single cell, with concomitant replication and segregation of genetic material.

The set of environmental conditions that results in the greatest growth rate for a given type of organism.

Organisms that use organic compounds as a carbon source.

Organisms that use reduced inorganic compounds as electron donors for energy generation.

Organisms that grow optimally in the range of $25-40^{\circ} \mathrm{C}$.

A class of low-molecular-weight proteins synthesized by a number of cell types that contain a high percentage of cysteine residues and bind selected metal ions.

Organisms that generate methane as a metabolic end product through the use of $\mathrm{CO}_{2}$ as a terminal electron acceptor.

Referring to habitats that are either low in essential nutrients, or those in which nutrients are unavailable to organisms.

In the presence of oxygen.

High-molecular-weight carbohydrate polymers containing many monomeric sugar subunits connected by covalent bonds; "heteropolysaccharides" contain two or more types of sugar monomer.

Organisms that are capable of growth at low temperatures.

Those conditions that result in some subset of a population surviving and growing at greater rates than other portions of the same population. 
siderophore

spore

thermophile
A class of small iron-binding molecules secreted by bacterial cells.

A structurally distinct and highly resistant cell type that forms from a growing or dormant cell in the presence of adverse environmental conditions.

Organisms that grow optimally at temperatures of $45-80^{\circ} \mathrm{C}$. 


\section{References}

Anderson, A. W., H. D. Horden, R. F. Cain, G. Parrish, and D. Duggan (1956).

"Studies on a radio-resistant micrococcus. I. Isolation, morphology, cultural characteristics and resistance to gamma irradiation." Food Technol. 10: 575-578.

Atlas, R. M., and R. Bartha (1981). Microbial Ecology: Fundamentals and Applications. Menlo Park, CA, Addison-Wesley Publishing Co.

Bachofen, R. (1991). "Gas metabolism of microorganisms." Experientia 47: 508-512.

Barnes, C. E., and J. K. Cochran (1993). "Uranium geochemistry in estuarine sediments: Controls on removal and release processes." Geochim. Cosmochim. Acta 19: 555-569.

Baross, J. A., and J. W. Deming (1983). "Growth of 'black smoker' bacteria at temperatures of least $250^{\circ} \mathrm{C}$." Science 303: $423-426$.

Birch, L., and R. Bachofen (1990). "Complexing agents from microorganisms." Experientia 46: 827-834.

Borenstein, S. W. (1994). Microbiologically Influenced Corrosion Handbook. New York, NY, Industrial Press, Inc.

Brock, T. D., and M. T. Madigan (1991). Biology of Microorganisms. Englewood Cliffs, New Jersey, Prentice-Hall, Inc.

Brown, A. D. (1976). “Microbial water stress.” Bacteriol Rev. 40: 803-846.

Brunke, M., E.-D. Deckwer, A. Frischmuth, J. M. Horn, H. Lunsdorf, M. Rhode, M. Rohricht, K. N. Timmis, and P. Weppen (1993). "Microbial retention of mercury from waste streams in a laboratory column containing merA gene bacteria." FEMS Microbiol. Rev. 11: 145-152.

Bulman, R. A. (1978). "Chemistry of plutonium and the transuranics in the biosphere." Structure and Bonding 34: 39-77.

Cervantes, C. (1991). "Bacterial interactions with chromate." Antonie van Leeuwenhoek 59: 229-233. 
Chapelle, F. H. (1993). Ground-Water Microbiology and Geochemistry. New York, NY, John Wiley and Sons, Inc.

Csonka, L. N. (1989). "Physiological and genetic responses of bacteria to osmotic stress." Microbiol. Rev. 53: 121-147.

Diercks, M. S. W., and E. Bock (1991). "Microbial corrosion of concrete." Experientia 47: 514-516.

Foster, J. W., and H. K. Hall (1991). "Inducible $\mathrm{pH}$ homeostasis and the acid tolerance response of Salmonella typhimurium." J. Bacteriol. 173: 5129-5135.

Francis, A. J. (1990). "Microbial dissolution and stabilization of toxic metals and radionuclides in mixed wastes." Experientia 46: 840-851.

Francis, A. J., and C. J. Dodge (1988). "Anaerobic microbial dissolution of transition and heavy metal oxides." Appl. and Environ. Microbiol. 54: 1009-1014.

Freifelder, D. (1987). Molecular Biology. Boston, MA, Jones and Bartlett Publishers, Inc.

Gadd, G. M. (1990). "Heavy metal accumulation by bacteria and other microorganisms." Experientia 46: 834-840.

Geesey, G. (1993). A Review of the Potential for Microbially Influenced Corrosion of High-Level Nuclear Waste Containers. Nuclear Regulatory Commission, Center for Nuclear Waste Regulatory Analyses, Report No. CNWRA 93-014. Southwest Research Inst., San Antonio, TX.

Geesey, G. G. (1991). "What is biocorrosion?" Biofouling and Biocorrosion in Industrial Water Systems. Ed. H. C. F. a. G. G. Geesey. Heidelberg, SpringerVerlag.

Haldeman, D. L., and P. S. Amy (1993). "Bacterial heterogeneity in deep subsurface tunnels at Rainier Mesa, Nevada Test Site." Microb. Ecol. 25: 183-194.

Haldeman, D. L., P. S. Amy, D. Ringelberg, and D. C. White (1993). "Characterization of the microbiology within a $21-\mathrm{m}^{3}$ section of rock from the deep subsurface." Microb. Ecol. 26: 145-159. 
Haldeman, D. L., B. J. Pitonzo, S. P. Story, and P. S. Amy (1994). "Comparison of the microbiota recovered from subsurface and deep subsurface rock, water, and soil along an elevational gradient." Geomicrobiol. J. 12: 99-111.

Hiebert, F., and P. C. Bennett (1992). "Microbial control of silicate weathering in organic-rich groundwater." Science 258: 278-281.

Jenkins, D. E., A. E. Auger, and A. Matin (1991). "Role of RpoH, a heat shock regulator protein, in Escherichia coli carbon starvation protein synthesis and survival." J. Bacteriol. 173: 1992-1996.

Kagi, J. H. R., and Y. Kojima (1987). Chemistry and Biochemistry of Metallothionein. Mettallothionein II. Basel, Birkhauser Verlag.

Knauss, K. G., W. L. Bourcier, K. D. McKeegan, C. I. Merzbacher, S. N. Nguyen, F. J. Ryerson, D. K. Smith, H. C. Weed, and L. Newton (1990). "Dissolution kinetics of a simple nuclear waste glass as a function of $\mathrm{pH}$, time, and temperature." Mat. Res. Soc. Symp. Proc. 176: 371-381.

Krauter, P., and D. McQueen (1995). “Effect of subsurface electrical heating and steam injection on the fatty acid methyl ester composition of lipids of indigenous organisms." Appl. Environ. Microbiol., submitted.

Kristjansson, J. K., and G. O. Hreggvidsson (1995). "Ecology and habitats of extremophiles." World J. Microbiol. and Biotechnol. 11: 17-25.

Krulwich, T. A., and A. A. Guffanti (1989). "Alkalophilic bacteria." Ann. Rev. Microbiol. 43: 435-463.

Lappin-Scott, H. M., F. Cusack, and J. W. Costerton (1988). "Nutrient resuscitation and growth of starved cells in sandstone cores: a novel approach to enhanced oil recovery." Appl. Environ. Microbiol. 54: 1373-1382.

Lee, W., A. Lewandowski, P. H. Nielsen, and W. A. Hamilton (1995). "Role of sulfate-reducing bacteria in corrosion of mild steel: a review." Biofouling 8 : 165-194. 
Lehninger, A. L., D. L. Nelson, and M. M. Cox (1993). Principles of Biochemistry. New York, NY, Worth Publishers.

Li, Y., L. Mandelco, and J. Wiegel (1993). "Isolation and characterization of a moderately thermophilic anaerobic alkalinophile, Clostridum paradoxum sp. nov." Intl. J. Syst. Bacteriol. 43: 450-460.

Libert, M. F., R. Sellier, G. Jouguet, M. Trescinski, and H. Spor (1992). "Effects of microorganisms on the long-term stability of cement and bitumen." Mater. Res. Soc. Proc., Boston.

Little, B. J., P. Wagner, and F. Manfeld (1992). "An overview of microbially influenced corrosion." Electrochim. Acta 37: 2185.

Lorowitz, W. H., D. P. Nagle, and R. S. Tanner (1992). "Anaerobic oxidation of elemental metals coupled to methanogenesis by Methanobacterium thermoautotrophicum." Environ. Sci. Technol. 26: 1606-1610.

Loosdrecht, M. C.M., J. Lyklema, W. Norde, and A. J. B. Zehndler (1990). "Influence of interfaces on microbial activity." Microbiol. Rev. 54: 75-87.

Lovley, D. R. (1993). “Dissimilatory metal reduction." Ann. Rev. Microbiol. 47: 263290.

Lovley, D. R., and E. J. P. Phillips (1992). "Reduction of uranium by Desulfovibrio desulfuricans." App. Environ. Microbiol. 58: 850-856.

Lovley, D. R., E. J. P. Phillips, Y. A. Gorby, and E. R. Landa (1991). “Microbial reduction of uranium." Nature 350: 413-416.

Lovely, D. K., F. H. Chapelle, and P., P. E. J. (1990). "Fe(III)-reducing bacteria in deeply buried sediments of the Atlantic Coastal Plain." Geology 18:954-957.

MacLeod, F. A., H. M. Lappin-Scott, and J. W. Costerton (1988). "Plugging of a model rock system using starved bacteria." Appl. Environ. Microbiol. 54: 1365-1372. 
McCann, M. P., J. P. Kidwell, and A. Matin (1991). "The putative $\sigma$ factor KatF has a central role in development of starvation-mediated general resistance in Escherchia coli." J. Bacteriol. 173: 4188-4194.

McKinley, I. G., and I. Hagenlocher (1993). Quantification of Microbial Activity in a Nuclear. Waste Repository. ISSM, Bath, England.

McMahon, P. B., and F. H. Chapelle (1991). "Microbial production of organic acids in aquitard sediments and its role in aquifer chemistry." Nature 349:2 33-235.

McMahon, P. B., F. H. Chapelle, W. F. Falls, and P. M. Bradley (1992). "Role of microbial processing in linking sandstone diagenesis with organic rich clays." J. Sed. Petrology 62: 1-10.

Moffat, A. S. (1994). "Microbial mining boosts the environment, bottom line." Science 264: 778-779.

Morita, R. Y. (1975). “Psychrophilic bacteria.” Bacteriol. Rev. 39: 144-167.

Nielands, J. B. (1981). "Microbial iron compounds." Ann. Rev. Biochem. 50: 715731.

Perfettini, J. V., E. Revertegat, and N. Langomazino (1991). “Evaluation of cement degradation induced by the metabolic products of two fungal strains." Experientia 47: 527-533.

Pope, D. H., R. J. Soracco, and E. W. Wilde (1982). "Studies on biologically induced corrosion in heat exchanger systems at the Savannah River Plant, Aiken, SC." Materials Perform. 21: 43-50.

Pope, D. H., S. Lockwood, A. Lee, R. Skultety, and K. Keas (1994). “Mitigation of microbiologically influenced corrosion in natural gas storage facilities." Paper No. 269, Corrosion '94 Annual Conference and Corrosion Show, Houston, TX, 1994.

Premuzic, E. T., A. J. Francis, M. Lin, and J. Schubert (1985). “Induced formation of chelating agents by Pseudomonas aeruginosa grown in the presence of thorium and uranium." Archs. Environ. Contam. Toxicol. 14: 759-768. 
Reeve, J. N. (1994). "Thermophiles in New Zealand." ASM News 60: 541-545.

Rogers, H. J., C. Synge, and V. E. Woods (1980). "Antibacterial effect of scandium and indium complexes of enterochelin on Klebsiella pneumoniae." Antimicrob. Agents Chemother. 18: 63-68.

Rogers, R. (1995). "Assessment of the effects of microbially influenced degradation on a massive concrete structure." Final report supplied to the Introduced Materials Task, Yucca Mountain Project, unpublished.

Russell, C. E., R. Jacobsen, D. L. Haldeman, and P. S. Amy (1994). "Heterogeneity of deep subsurface microorganisms and correlations to hydrogeological and geochemical parameters." Geomicrobiol. J. 12: 37-51.

Sand, W., and E. Bock (1991). "Biodeterioration of ceramic materials by biogenic acid." International Biodeterioration : 175-181.

Shaw, J. C., B. Bramhill, N. C. Wardlaw, and J. W. Costerton (1985). "Bacterial fouling in a model core system." Appl. and Environ. Microbiol. 49: 693-701.

Slonczewski, J. L., T. N. Gonzalez, F. M. Bartholomew, and N. J. Holt (1987). "Muddirected lacZ fusions regulated by low pH in E. coli." J. Bacteriol. 169: 3001-3006.

Stanier, R. Y., E. A. Adelberg, and J. L. Ingraham (1976). The Microbial World. Englewood Cliffs, NJ, Prentice-Hall, Inc.

Staudigel, H., R. A. Chastain, A. Yayanos, and W. Bourcier (1995). "Biologically mediated dissolution of glass." Chem. Geol. 26 (in press).

Stetter, K. O. (1995). "Microbial life in hyperthermal environments." ASM News 61(June): 285-290.

Straus, D. B., W. A. Walter, and C. A. Gross (1987). "The heat shock response of $E$. coli is regulated by changes in the concentration of $\sigma^{32 . "}$ Nature 329: 348-351.

Stroes-Gascoyne, S. (1994). Microbial Issues Pertaining to the Canadian Concept for the Disposal of Nuclear Fuel Waste. Atomic Energy of Canada Limited, Report No. AECL-10808, COG-93-54. Whiteshell Nuclear Research Establishment, Pinawa, Manitoba. 
Stroes-Gascoyne, S., L. M. Lucht, J. Borsa, T. L. Delaney, S. A. Haveman, and C. J. Hamon (1994). Radiation resistance of the natural microbial population in buffer materials. Materials Research Society Symposium on Scientific Basis for Nuclear Waste Management XVIII, Kyoto, Japan, Materials Research Society.

Stroes-Gascoyne, S. (1989). The Potential for Microbial Life in a Canadian HighLevel Nuclear Waste Disposal Vault: A Nutrient and Energy Source Analysis. Atomic Energy of Canada Limited, Report No. AECL-9574. Whiteshell Nuclear Research Establishment, Pinawa, Manitoba.

Summers, A. O. (1986). "Organization, expression, and evolution of genes for mercury resistance." Ann. Rev. Microbiol. 40: 607-634.

Suutari, M., and S. Laakso (1994). "Microbial fatty acids and thermal adaptation." Crit. Rev. Microbiol. 20: 285-328.

Thorseth, I. H., H. Furnes, and M. Heldal (1992). "The importance of microbiological activity in the alteration of basaltic glass." Geochim. Cosmochim. Acta 56: 845850 .

Tompson, A. F. B., R. B. Knapp, M. L. Hanna, and R. T. Taylor (1994). "Simulation of TCE migration and biodegradation in a porous medium under conditions of finite degradation capacity." Adv. Water Res. 17: 241-249.

Wolery, T. J. (1992a). EQ3NR, a computer program for geochemical aqueous speciation-solubility calculations, version 7.0. Lawrence Livermore National Laboratory, U.S. Dept. of Energy, Livermore, CA.

Wolery, T. J. (1992b). EQ6, a computer program for reaction path modeling of aqueous geochemical systems (version 7.0). Lawrence Livermore National Laboratory, U.S. Dept. of Energy, Livermore, CA. 

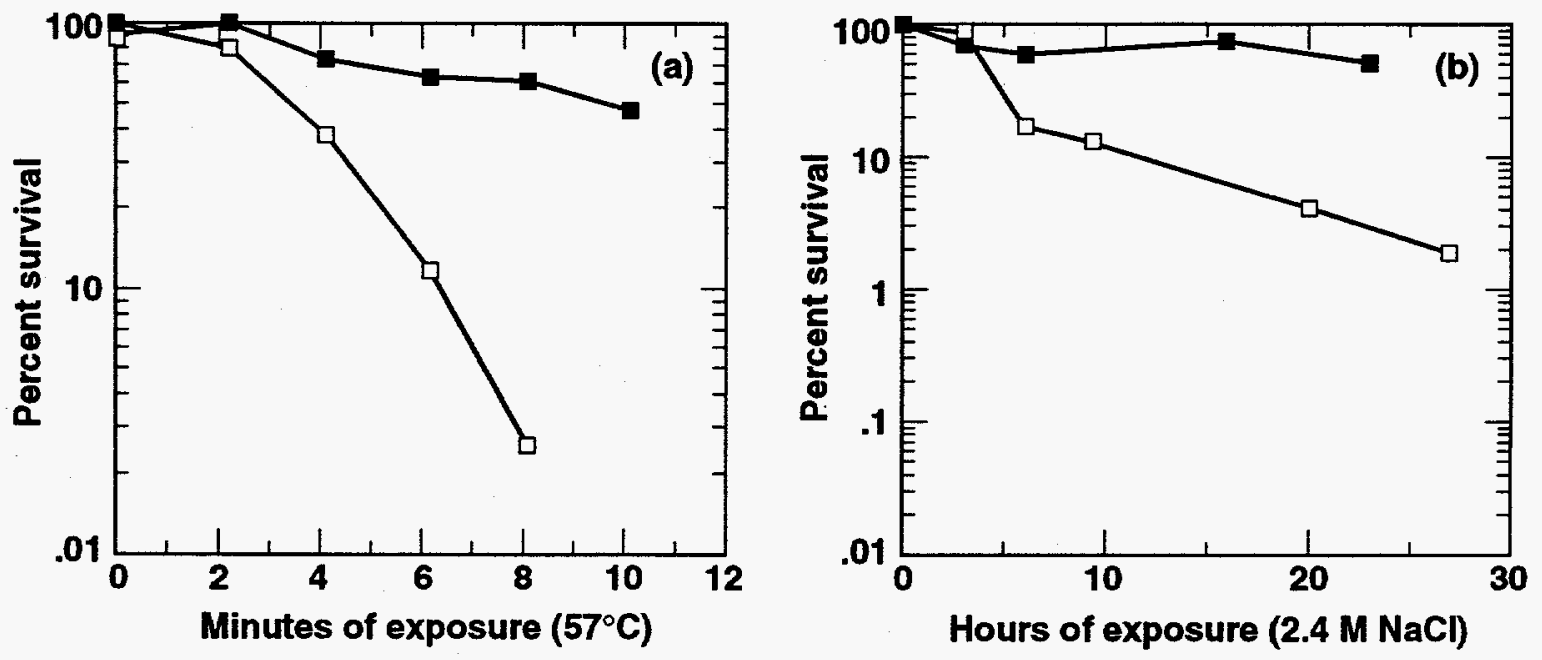

Fig. 1. Cross of resistance to various stressors. Starved Escherichia coli cells ( $\square$ ) demonstrate greater survival when (a) exposed to elevated temperatures and (b) increased salt concentrations than unstarved cells (ㅁ) (After McCann et al., 1991). 


\section{Redox Cycles of Essential Elements}

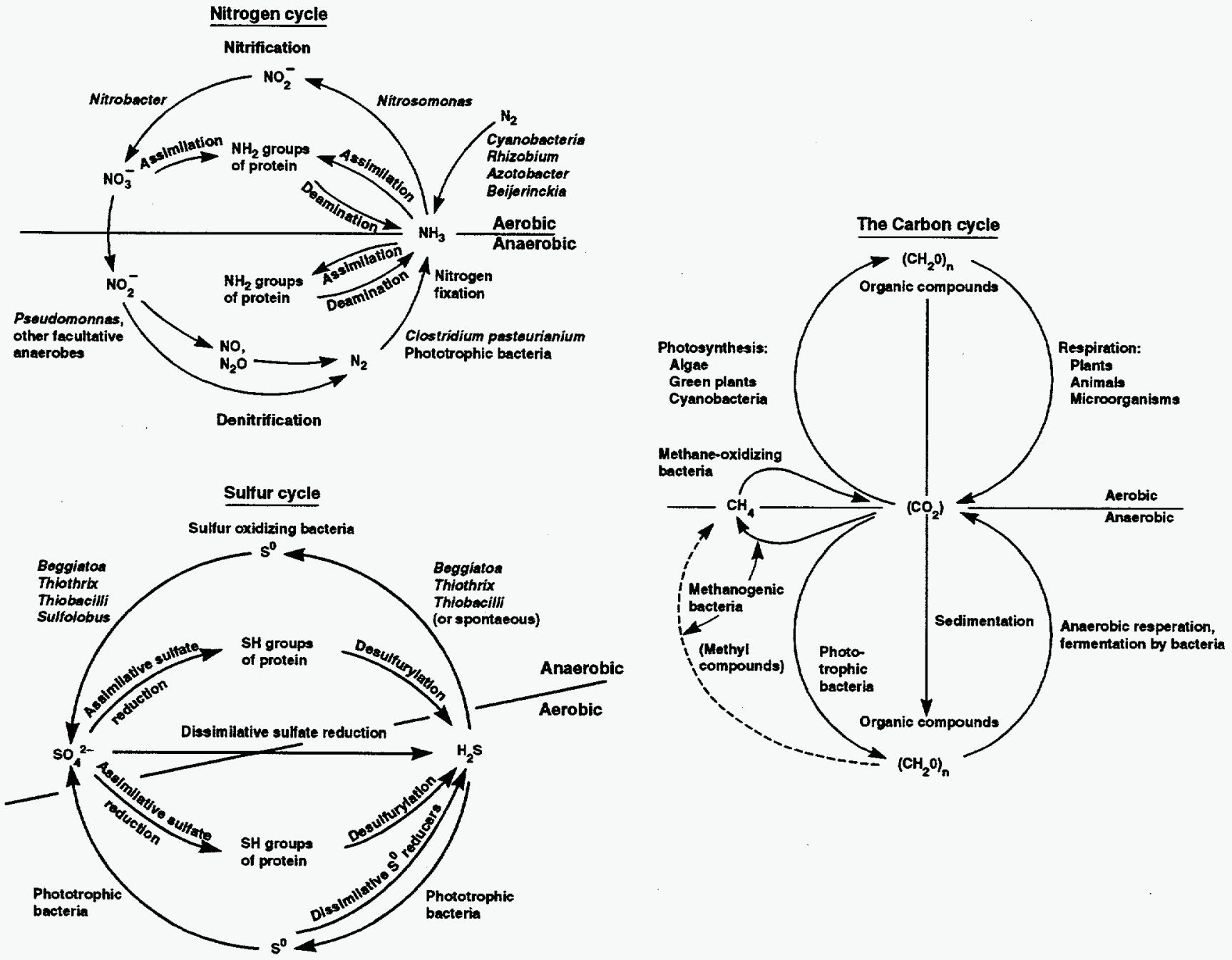

Fig. 2. After Brock and Madigan (1991). 


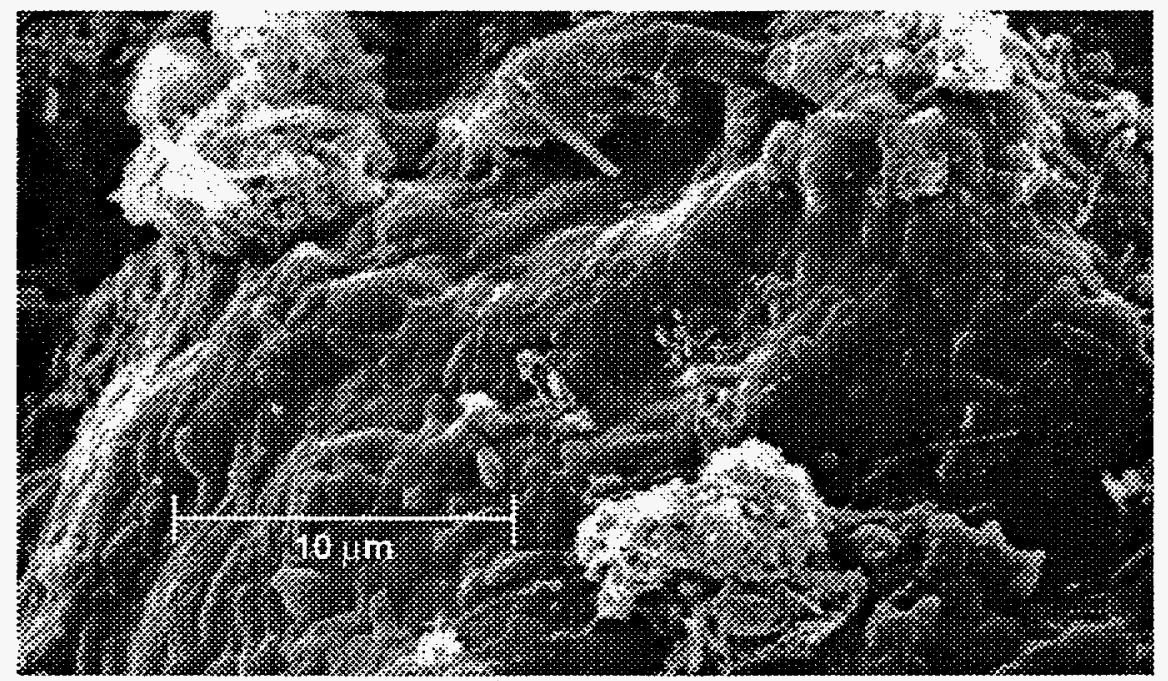

Fig. 3. Biofilm formation on cement in a geothermal cooling tower, Ohaaki, New Zealand. Biofilm material forms various microenvironments, allowing the growth of bacteria (rod-shaped) in various niches (Rogers, 1995). 


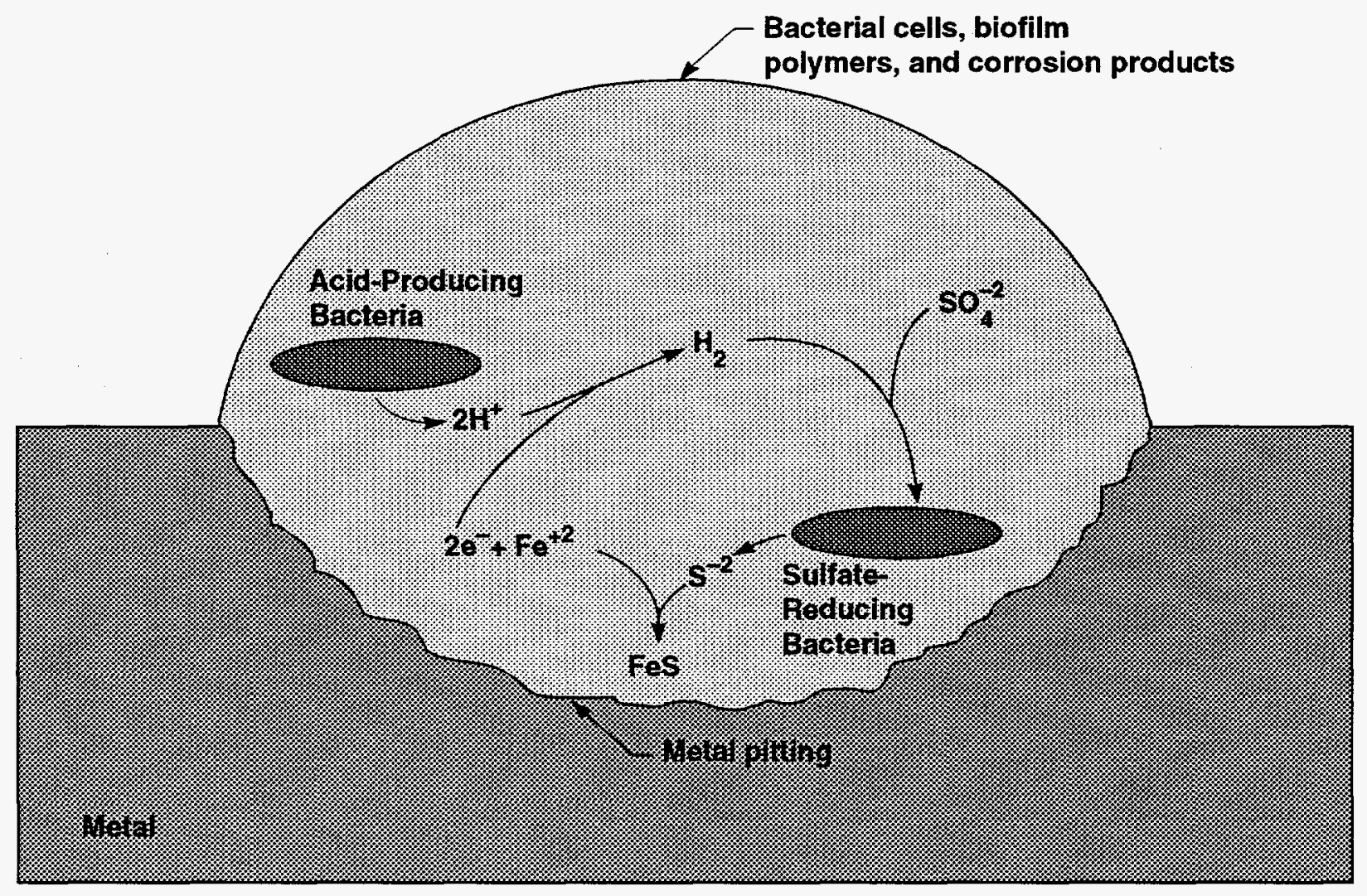

Fig. 4. Microbial contributions to metal corrosion. Acid-producing bacteria generate protons that contribute to metal dissolution and form hydrogen when coupled with corrosion-generated electrons. The resulting hydrogen, together with sulfate, is consumed by sulfate-reducing bacteria, resulting in sulfide production. Consumption of hydrogen by sulfate reducers drives corrosion by eliminating the layer of hydrogen that would otherwise occlude the metal surface, a process termed "cathodic depolarization." Sulfide couples with dissolved ferrous ions to form ferrous sulfide. Ferrous ions also bind chlorine and hydroxide ions, generating iron chlorides and hydroxides, respectively (after Pope et al., 1994). 


\section{Limits to Microbial Activity}

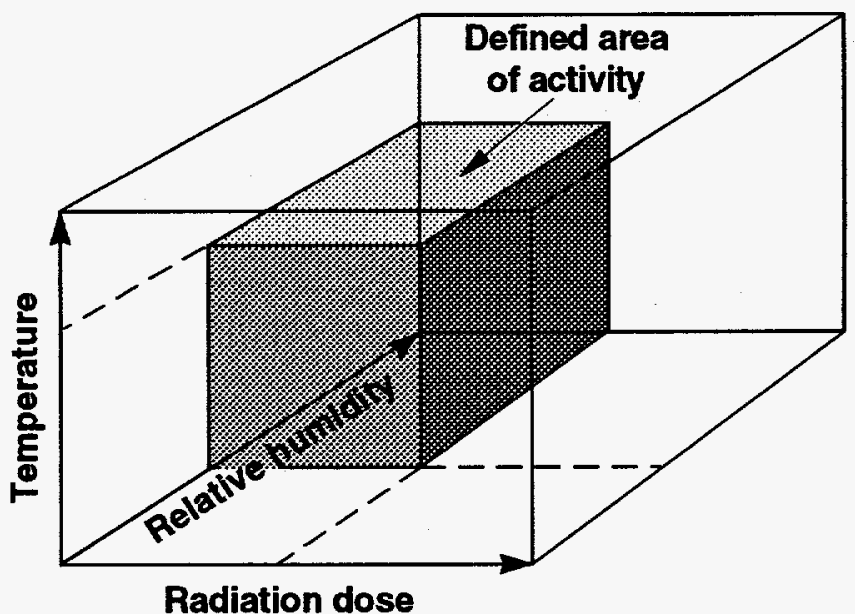

Fig. 5. It should be possible to define ranges of radiation dose, temperature, and relative humidity outside of which microbial activity ceases. A regular area of defined activity is depicted only as a theoretical first approximation. 


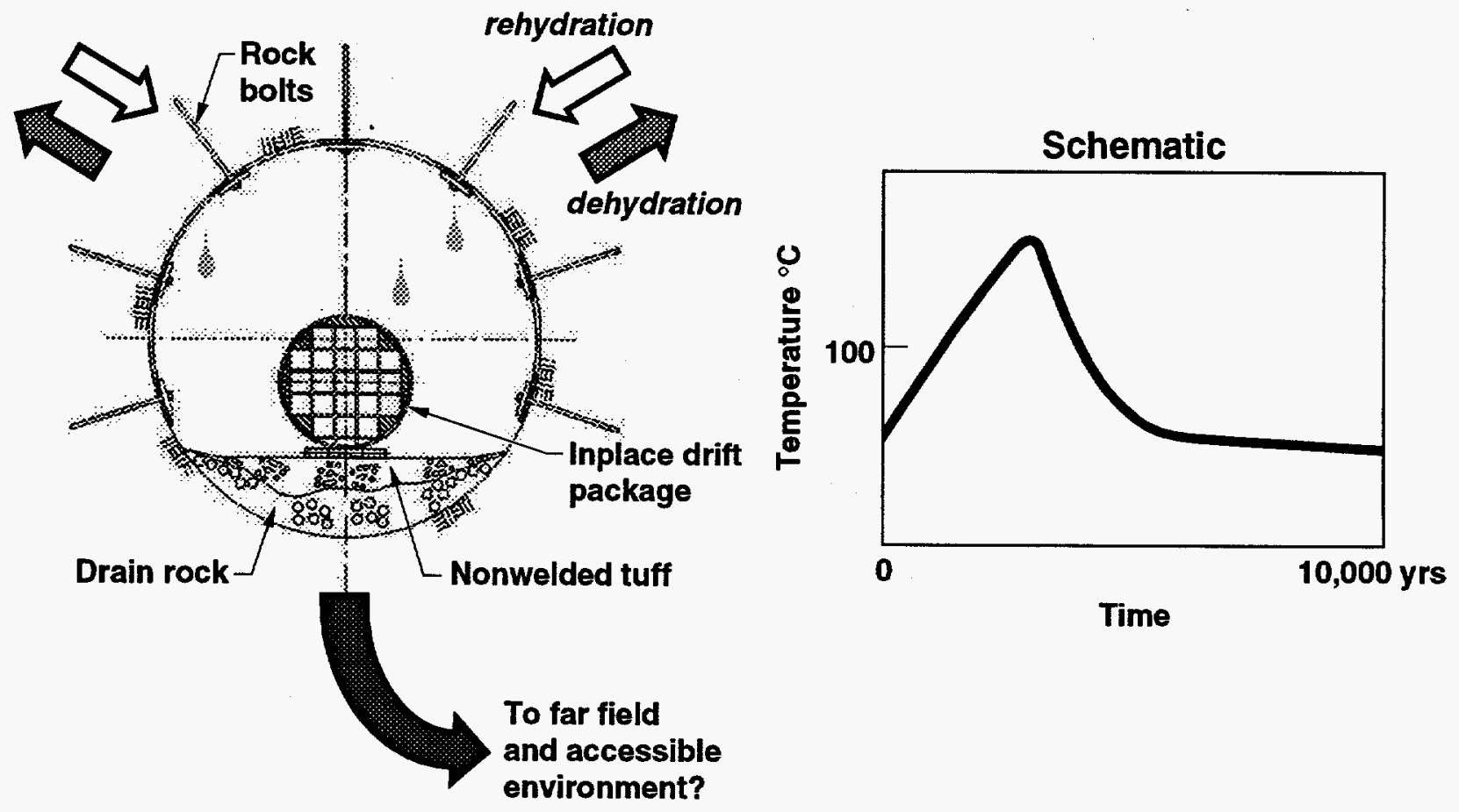

Fig. 6. Migration of water with temperature flux in the near-field environment. As temperature increases due to radionuclide decay pore water is expected to migrate away ( from the repository, and then return $(\smile)$ during the cooling period. Rehydration of the repository could facilitate transport of waste material by biotic and other means. 

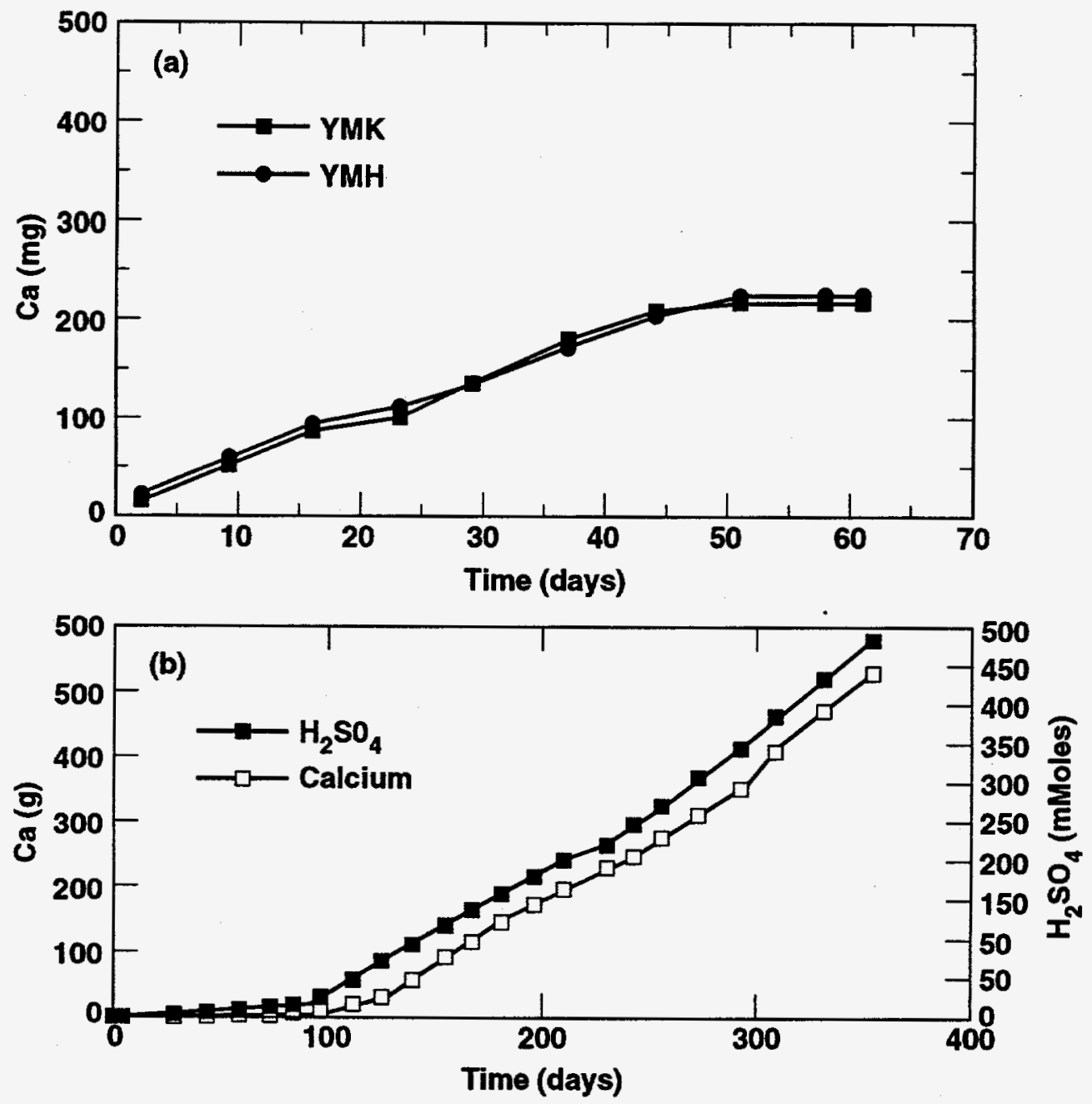

Fig. 7. Evolution of leached calcium from various cement formulations. (a) two proposed Yucca Mountain cements (YMK and YMH) after continuous exposure to media containing pregrown Thiobacillus thiooxidans, $\mathrm{pH} 2$ (after Rogers, 1995). (b) Portland cement in mineral medium inoculated with a mixed culture of Thiobacillus, with associated bacterially generated sulfuric acid production (after Libert et al., 1992). 


\section{Appendix}

\section{Attendees of the \\ Workshop on Microbial Activity at Yucca Mountain, April 10-12, 1995, Lafayette, California}

Penny Amy

Dept. of Biology

University of Nevada

4504 S. Maryland Pkwy.

Las Vegas, NV 89154

tel: 702-895-3399

fax: 702-895-3956

Susan Borenstein

San Jose Structural Integrity

3315 Alameda Expressway

Suite 24

San Jose, CA 95118

tel: $408-978-8200$

fax: 408-978-8964

Bill Bourcier

LLNL

P.O. Box 808, L-219

Livermore, CA 94550

tel: $510-423-3745$

fax: $510-422-0208$

Dan Bullen

Iowa State University

Nuclear Eng. Program

107 Nuclear Engineering Lab

Ames, IA 50010-2241

tel: 515-294-9380

fax: 515-294-7224

Ching-I Chen

LLNL

P.O. Box $808, \mathrm{~L}-532$

Livermore, CA 94550

tel: $510-422-5661$

fax: $510-422-2282$
Doug Clark

Chem. Eng. Dept.

University of Calif. Berkeley

Berkeley, CA 94720

fax: $510-642-4778$

Bill Costerton

Center for Biofilm Eng.

Montana State Univ.

Bozeman, MT 59717

tel: 406-994-1960

fax: 406-994-6098

Bill Glassley

LLNL

P.O. Box 808, L-202

Livermore, CA 94550

tel: 510-422-6499

fax: 510-422-1002

Dana Haldeman

Dept. of Biology

University of Nevada 4504 S. Maryland Pkwy.

Las Vegas, NV 89154

tel: 702-895-1146

fax: 702-895-3956

Larry Hersman

Life Sciences-2, Mailstop-M880

Los Alamos Nat'l. Laboratory

Los Alamos, NM 87545

tel: 505-667-2779

fax: 505-665-3024 
Joanne Horn

LLNL

P.O. Box $808, \mathrm{~L}-206$

Livermore, CA 94550

tel: $510-423-3949$

fax: 510-422-3118

\section{Ken Jackson}

LLNL

P.O. Box 808, L-207

Livermore, CA 94550

tel: $510-422-6053$

fax: $510-422-318$

\section{Denny Jones}

Dept. of Chem. and Metal. Eng.

Mailstop 170

University of Nevada

Reno, NV 89557

tel: 702-784-6021

fax: 702-784-1766

Stevan Jovanovich

Molecular Solutions

4749 Bennet Dr., Suite C

Livermore CA 94550

tel: 510-606-8601

fax: 606-8602

John Kessler

EPRI

3412 Hillview Ave.

P.O. Box 10412

Palo Alto, CA 94303-0813

tel: $415-855-2069$

fax: $415-855-2774$

Richard Knapp

LLNL

P.O. Box 808 , L-206

Livermore CA 94550

tel: $510-423-3328$
Whonchee Lee

493 South Browning Ave.

Boise, ID 83709

tel: 208-375-4977

\section{George Licina}

San Jose Structural Integrity

3315 Alameda Expressway

Suite 24

San Jose, CA 95118

tel: $408-978-8200$

fax: 408-978-8964

Lars Ljungdahl

Dept. of Biochemistry

University of Georgia

Athens, GA 30602-7229

tel: 706-542-7640

fax: 706-542-2222

\section{Abdul Matin}

Stanford University

Microbiology Dept.

Stanford, CA 94305

tel: 415-725-4745 (Micro Dept.)

fax: 415-725-6757

\section{R. Daniel McCright}

LLNL

P.O. Box 808, L-369

Livermore CA 94550

tel: 510-422-7051

fax: $510-422-2118$

Annemarie Meike

LLNL

P.O. Box 808, L-201

Livermore CA 94550

tel: 510-422-3735

fax: 510-423-1057

Richard Morita

Dept. Microbiology

Oregon State University

Corvallis, OR 97331-3804

tel: 503-737-1862

fax: 503-737-0496 
Larry Ramspott

TRW Environmental Safety

Systems, Inc.

LLNL

P.O. Box 808, L-204

Livermore CA 94550

tel: $510-422-4176$

\section{Frank Robb}

Univ. of Maryland

Center for Marine Biotechnology

701 E. Pratt St.

Baltimore MD 21202-4031

tel: $410-234-8870$

fax: $410-234-8896$

\section{Robert Rogers}

Biodegradation Systems, Inc.

1206 Norton

Idaho Falls, ID 83402

tel: 208-526-0685

fax: 208-526-0828

Nilesh Shah

LLNL

P.O. Box 808, L-532

Livermore, CA 94550

tel: $510-422-2236$

fax: 510-422-2282

\section{Dave Stahl}

B \& W Fuel Company

101 Convention Center Drive

Suite P-110

Las Vegas, NV 89109

tel: 702-794-7778

fax: 702-794-1844

\section{Ray Stout}

LLNL

P.O. Box $808, \mathrm{~L}-201$

Livermore, CA 94550

tel: $510-422-3965$

fax: $510-423-1057$
Simcha Stroes-Gascoyne

White Shell Laboratory

AECL Research

Pinawa, Manitoba R0E 1L0

CANADA

tel: 204-753-2599

fax: 204-753-2455

David C. White

University of Tennessesee

10515 Research Dr., Suite 300

Knoxville, TN 37932

tel: 615-974-8001

fax: 615-974-8027

Jim Wolfram

INEL

P. O. box $1625, \mathrm{~m} / \mathrm{s} 2203$

Idaho Falls, ID 83415

tel: 208-526-1809

fax: 208-526-0828

Art Yayanos

UCSD/SIO/3115 Hubbs Hall

9500 Gillman Drive

Dept. 0202

La Jolla, CA 92093-0202

tel: 619-534-2935

fax: 619-534-7313 
